\title{
Somatic mutations in neurons during aging and neurodegeneration
}

\author{
Bert M. Verheijen ${ }^{1,2} \cdot$ Marc Vermulst $^{3} \cdot$ Fred W. van Leeuwen $^{4}$ \\ Received: 18 March 2018 / Revised: 20 April 2018 / Accepted: 21 April 2018 / Published online: 28 April 2018 \\ (c) The Author(s) 2018
}

\begin{abstract}
The nervous system is composed of a large variety of neurons with a diverse array of morphological and functional properties. This heterogeneity is essential for the construction and maintenance of a distinct set of neural networks with unique characteristics. Accumulating evidence now indicates that neurons do not only differ at a functional level, but also at the genomic level. These genomic discrepancies seem to be the result of somatic mutations that emerge in nervous tissue during development and aging. Ultimately, these mutations bring about a genetically heterogeneous population of neurons, a phenomenon that is commonly referred to as "somatic brain mosaicism". Improved understanding of the development and consequences of somatic brain mosaicism is crucial to understand the impact of somatic mutations on neuronal function in human aging and disease. Here, we highlight a number of topics related to somatic brain mosaicism, including some early experimental evidence for somatic mutations in post-mitotic neurons of the hypothalamo-neurohypophyseal system. We propose that age-related somatic mutations are particularly interesting, because aging is a major risk factor for a variety of neuronal diseases, including Alzheimer's disease. We highlight potential links between somatic mutations and the development of these diseases and argue that recent advances in single-cell genomics and in vivo physiology have now finally made it possible to dissect the origins and consequences of neuronal mutations in unprecedented detail.
\end{abstract}

Keywords Somatic mutations · Genome integrity $\cdot$ Somatic brain mosaicism $\cdot$ Neuronal development $\cdot$ Aging · Neurological disorders $\cdot$ Neurodegeneration

\section{Introduction}

The vertebrate nervous system is a highly complex structure that is composed of many different cell types, including various types of neurons. This complexity enables specialized functions that are essential for proper organismal functioning. Although the physiological details that underlie this

Bert M. Verheijen

1.m.verheijen-3@umcutrecht.nl

1 Department of Translational Neuroscience, Brain Center Rudolf Magnus, University Medical Center Utrecht, 3584 CG Utrecht, The Netherlands

2 Department of Neurology and Neurosurgery, Brain Center Rudolf Magnus, University Medical Center Utrecht, 3508 GA Utrecht, The Netherlands

3 Department of Pathology and Laboratory Medicine, Children's Hospital of Philadelphia, Philadelphia, PA 19104, USA

4 Department of Neuroscience, Faculty of Health, Medicine and Life Sciences, Maastricht University, 6229 ER Maastricht, The Netherlands complexity remain unclear, it is at least partially mediated by the heterogeneity of neurons themselves, which can differ greatly in their morphology, as well as their connectivity and electrophysiological activity. Recent advances in single-cell expression profiling now allow us to explore this diversity further at the molecular level, and revealed that an even greater diversity of neuronal subtypes exists than previously expected, even within single brain regions composed of seemingly identical neurons $[65,66,96,150]$. Although many studies using these experimental approaches are hampered by small sample sizes, a lack of time-points and inadequate assessment of distinct cellular states, it is anticipated that these technological innovations will ultimately lead to the identification of novel cell types, and contribute to a better systematic categorization of neurons [101]. In doing so, these experiments will greatly enhance our understanding of the origins and implications of cellular diversity within the nervous system [94] and elucidate how this diversity impacts neuronal function and disease.

In addition to tightly orchestrated programs that differentiate neurons into highly specialized subtypes, a growing 
body of evidence indicates that neurons can also differ at the genomic level [8, 42]. During neuronal development, somatic mutations may arise in neuronal stem/progenitor cells that are propagated throughout the neural lineage these cells spawn. This propagation leads to the formation of a "mosaic patchwork" of genetically different neurons, a phenomenon that is commonly referred to as "somatic brain mosaicism" (Fig. 1). By altering the genetic makeup of cells, these mutations could perturb critical aspects of neuronal function and contribute to various neurological diseases $[70,85,98,100]$. For example, neuronal mutations could affect genetic programs that define neuronal identity or alter properties that are essential to the development and plasticity of neural circuits, such as the organization of dendritic spines and axonal boutons, or the efficiency of synaptic transmission. Similar changes could affect the selective vulnerability of neuronal cells to insults and disease, and contribute to complex quantitative phenotypes, such as the genetic architecture of behavior and cognition. Moreover, randomly generated genetic diversity within the brain might, at least in part, explain personal differences between otherwise identical individuals [24]. It is compelling that the existence of a general "proantigen" that undergoes minor genomic changes during brain development, giving rise to a variety of "neurotypes", has already been proposed several decades ago [123].

However, age-related mutations in post-mitotic neurons, accumulating over the course of human aging, represent a relatively poorly studied group of mutations. They are of exceptional interest though, because aging is a major risk factor for many neurological diseases, including Alzheimer's disease (AD). Insights into the mechanisms and consequences of neuronal mutations could therefore lead to a better understanding of the etiology of disease progression and hint at novel strategies for therapeutic intervention. Intriguingly, this insight may even provide us with a better understanding of the aging process of the brain itself $[60$, $62,77,127]$.

In the present review, we highlight some of the early work on somatic mutations in the hypothalamo-neurohypophyseal system, which provided the first experimental evidence for somatic mutagenesis in aging neurons. Next, we delve into the mechanisms that could be responsible for somatic brain mosaicism and discuss the potential contribution of neuronal somatic mutations during development and aging to neuropathology. Finally, we present a road map to guide continued efforts to elucidate the somatic mutation burden in

\section{SOMATIC BRAIN MOSAICISM}

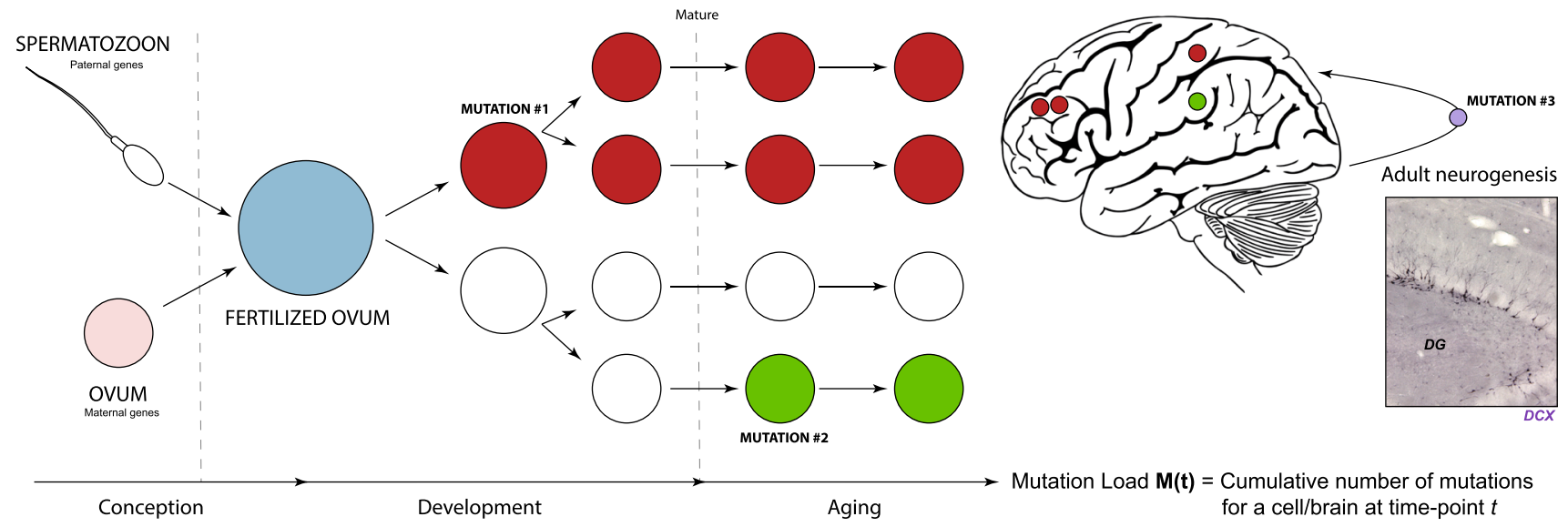

Fig. 1 Somatic mutations in the nervous system. The genome is a set of instructions, or a program, for the development and functioning of organisms. It is often considered to be a fixed chemical entity, which is faithfully copied from mother to daughter cells during successive rounds of cell division and is mostly identical in different cells from different tissues. However, it has become clear that differences in genomes exist between single cells. Some researchers have taken the view that no cell in an individual does, in fact, carry the exact same genetic scripture. This potentially has major implications, especially for post-mitotic cells like neurons that are rarely or not at all replaced during life. Throughout normal development, post-zygotic mutations occur in neural progenitors, which are inherited by their cellular progeny (mutation \#1). This will eventually culminate in a genetic mosaic. It has been suggested that somatic mutations can also take place in the developed nervous system (mutation \#2; neuro- genesis: mutation \#3). Mature neurons are generally considered to be terminally differentiated post-mitotic cells with limited regenerative potential. Therefore, they are particularly prone to accumulation of damage. Specifically, genomic integrity of neurons can be influenced by the occurrence of gene mutations. During aging, the nervous system is subjected to various types of stress that contribute to neuronal damage, including genomic alterations such as telomere shortening and chromosomal abnormalities. These changes are accompanied by various other alterations, like impaired nuclear integrity, aberrant nucleocytoplasmic transport and defects at the level of mitochondria (including mtDNA mutations). Insert shows a microscopic image of the dentate gyrus of a mouse hippocampus, immunostained for doublecortin (DCX), a marker for neurogenesis (Verheijen, Vermulst and van Leeuwen, unpublished) 
brain tissue and to better understand their impact on human aging and disease.

\section{Somatic mutations in vasopressin neurons}

Some of the earliest experimental evidence for mutations in post-mitotic neurons came from observations in the homozygous (di/di) Brattleboro rat, which carries a naturally occurring mutation in the vasopressin gene $(V P)[108,132]$. The di/di rat suffers from severe diabetes insipidus due to a single base deletion in exon B of the $V P$ gene, resulting in an abnormal VP precursor frameshift mutant (Fig. 2a). This frameshift mutant cannot translocate in the endoplasmatic reticulum (ER) and, therefore, cannot be axonally transported towards the neural lobe of the neurohypophysis where it is secreted into the circulation (Fig. 2d).

Surprisingly, immunocytochemistry revealed that some solitary neurons in the hypothalamus of the KO rat are reactive for the VP precursor, as shown by immunoreactivity for its C-terminal glycopeptide (GP) domain (Fig. 2b) [132]. This finding indicated the occurrence of a post-mitotic mutation event $(+/ \mathrm{di})$ in these cells. Interestingly, the number of GP-positive neurons increases over age, suggesting an age-acquired cell reversal phenotype (Fig. 2c) [132, 135]. This age-dependent increase in reverted cells is remarkably linear, indicating a fixed mutation rate (approx. 1 cell/ week). Through this work, similar post-mitotic mutations were found in wild-type rats and in hypothalamic neurons in human brain [39, 41]. Of note, a similar age-related reversal phenomenon has been described to occur in liver of analbuminemic rats (for a detailed overview, see [46]).

It has later been proposed that the observed $V P$ mutations occur in certain repeat motifs (e.g., GAGAG motifs) at the RNA level, representing a specific type of transcription error $[19,133]$. Certain regions in the genome may be particularly prone to transcription errors due to polymerase slippage/ stuttering or other mechanisms. A comprehensive overview of the origins and consequences of errors in neuronal gene expression and its potential relation to VP is beyond the scope of this review (but see-Future directions- -Beyond the genome: neuronal epimutations"), but the notion of transcript mutations in di/di rats has been challenged by the observation that: (i) the reversal is an all or nothing event. In other words, only high levels of altered transcripts are present in select neurosecretory neurons or none at all, which is inconsistent with the presence of a transcript mutation; (ii) there is a constant increase in the number of reverted cells with age, suggesting an irreversible phenotype [40]. However, we cannot rule out the existence of some kind of RNA editing event causing this cell reversal phenotype. Notably, somatic DNA mutations may cause shifts in the accuracy of gene expression or affect control over genomic integrity itself (e.g., by affecting cellular machinery involved in regulating gene expression and cellular quality control mechanisms). Integrated DNA-RNA sequencing, i.e., DNA and RNA sequencing of the same reverted cells, could provide a definitive explanation for this phenomenon. Solitary VP neurons can be easily dissected under the microscope. If these experiments confirm that cellular reversal of the $V P$ gene is caused by a genetic mutation, the di/di rat might be a useful model system to study mechanisms of somatic mutation in the adult nervous system.

Since these early observations on the Brattleboro rats, reporter mice and highly sensitive single-cell sequencing techniques have been developed that have recently confirmed the existence of genetic mutations in post-mitotic neurons $[9,75]$. These studies now indicate that genetic mutations do not only occur in the $V P$ gene, but are also present throughout the genome of neuronal cells. As a result, these mutations can affect a wide variety of biological processes, which could affect the architecture of the brain and behavior in numerous ways. However, how these somatic mutations arise remains heavily debated.

\section{Mechanisms for somatic mutations in neurons}

In the developing nervous system, replication errors during S-phase are the best-known source of neuronal mutations. The rapidly proliferating neural progenitors that are responsible for populating the developing brain are exquisitely sensitive to errors that occur during DNA replication and chromosome segregation, two potent sources of de novo mutations. Interestingly, long neural genes are particularly prone to DNA breaks, which provides an intriguing explanation for a fraction of the observed variety in brain DNA [143, 144]. However, in the adult nervous system, which is primarily composed of post-mitotic cells that do not undergo DNA replication, replication errors cannot explain genomic differences (with the exception of cells that arise in the neurogenic niche of the subventricular zone and the dentate gyrus) [15, 36]. A fascinating relationship between attempted cell cycle re-entry $\left(\mathrm{G}_{0} \rightarrow \mathrm{S}\right)$ and neurodegeneration has recently drawn some attention though [27, 148]. Accordingly, both neurogenesis and early embryogenesis exhibit a drastic increase in mutagenesis compared to adulthood [9]. This observation suggests that other endogenous (spontaneous) and exogenous (environmental) factors must be responsible for the accumulation of mutations in post-mitotic cells (Fig. 3) [81].

Exogenous factors that are well known to induce mutagenesis include environmental stressors such as electromagnetic radiation, viruses, and mutagenic chemicals. A lifetime of exposure to these genotoxins is likely to induce mutations in aging neurons, although it should be noted that 
a

SOMATIC MUTATIONS IN VASOPRESSIN PRECURSORS

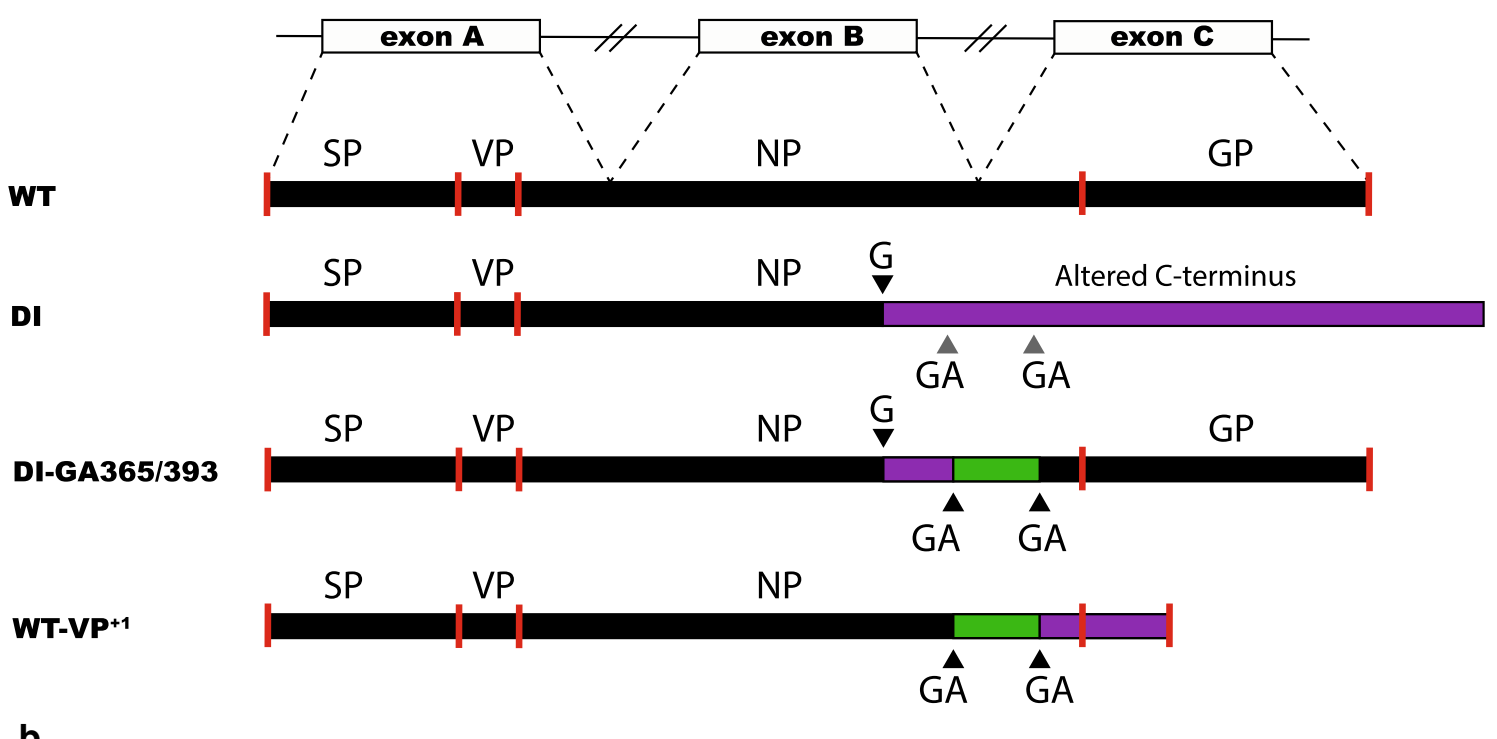

b
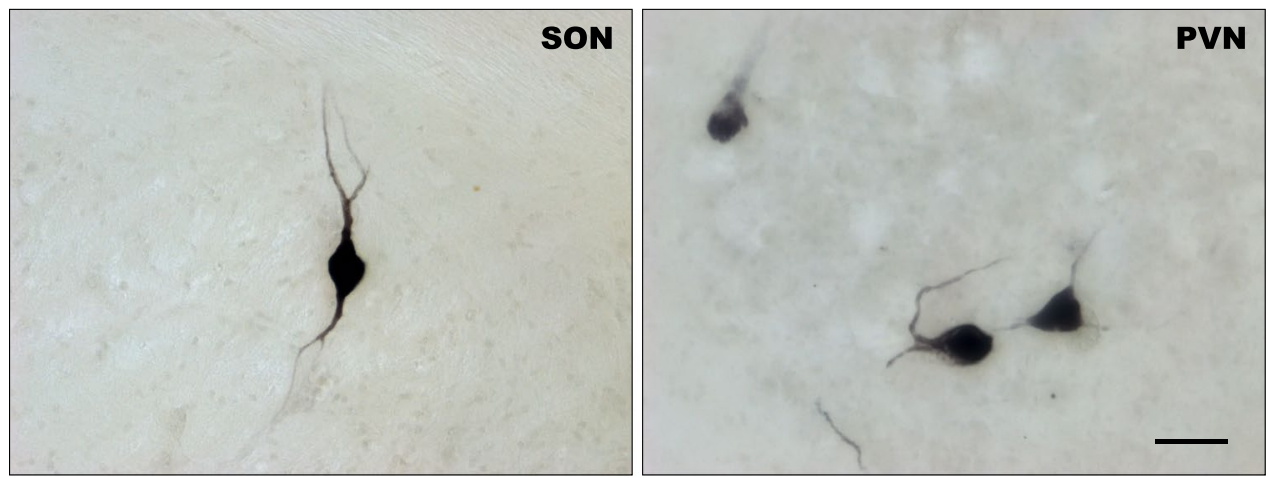

C

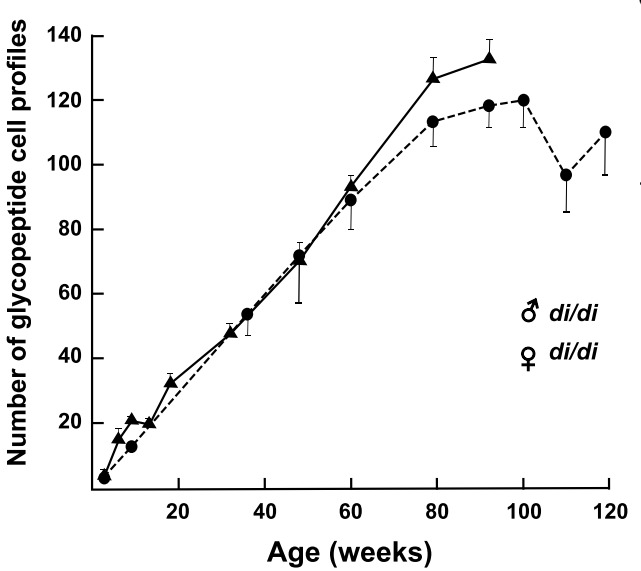

d

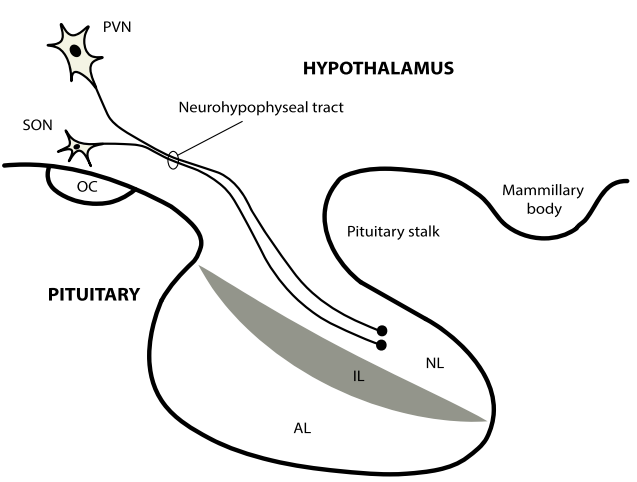

intra-uterine exposure to these toxins (e.g., through maternal smoking) could also introduce mutations in neurons during development [99].

Endogenously, multiple mechanisms contribute to mutational events. These include DNA damage, DNA replication, defective DNA damage repair, transcription, and metabolic processes (e.g., through the generation of reactive oxygen

species). Of these various processes DNA damage is an especially powerful source of somatic mutations. For example, single-base substitutions can be introduced by cytosine deamination events, a highly mutagenic lesion that can potentially result in transition mutations [63].

In the context of DNA damage, it is interesting to note that there might be an underappreciated role for neuronal 
४Fig. 2 Mutations in post-mitotic vasopressin neurons. a Schematic representation of the vasopressin $(V P)$ gene, VP prohormone and mutant forms. The $V P$ gene consists of three exons (exon A, B, and $\mathrm{C}$, consisting of 429 nucleotides), which give rise to a transcript that is spliced to generate the mRNA template for a precursor protein (WT). VP precursor protein is translated in the endoplasmatic reticulum (ER), post-translationally processed and packaged within neurosecretory granules. Subsequently, the protein is axonally transported to nerve terminals in the neural lobe of the pituitary gland $(\mathbf{d})$. In the homozygous (di/di) Brattleboro rat, a single base $(\mathrm{G})$ deletion in exon $\mathrm{B}$ results in an out-of-frame protein that contains a poly-lysine tail that cannot be properly processed $(D I)$. This results in (central) diabetes insipidus (DI), a condition that is characterized by polyuria and polydipsia, due to the inability to effectively regulate the VP-mediated retention of water in the kidney's collection ducts (antidiuretic function). This is an autosomal recessive trait that is inherited in a simple Mendelian fashion. b Intriguingly, some solitary neurons in the supraoptic nucleus (SON) and paraventricular nucleus (PVN) of the homozygous Brattleboro rat appear to be immunoreactive for VP. Bar $=50 \mu \mathrm{m}$ (Verheijen, Vermulst and van Leeuwen, unpublished). This appears to be due to a second mutation $(\Delta \mathrm{GA})$ in a GAGAG motif that is located downstream of the single base mutation (a). As a result the VP mutant precursor (DI-GA365/393) can be processed (i.e., the glycoprotein (GP)-containing part) and the neurosecretory granules can be axonally transported towards the neural lobe. The amount of reverted neurons ( $+/ \mathrm{di})$ increases age-dependently in both male (filled triangle) and female (filled circle) rats (c). Because GAGAG motifs are also present in the wild-type $V P$ gene of rat and human, a similar process can take place and convert the wild-type VP precursor into an aberrant one $\left(W T-V P^{+l}\right)$. This has been shown to occur in hypothalamus of both rat and human. $A L$ anterior lobe, $I L$ intermediate lobe, $N L$ neural lobe, $N P$ neurophysin, $O C$ optic chiasm, $S P$ signal peptide

activity in the generation of DNA damage. Physiological neuronal activity has been shown to induce double-strand breaks in DNA [124]. The VP neuron reversal events in di/ di rats mentioned in the previous section ("Somatic mutations in vasopressin neurons") appear to be related to activity status as well $[40,41]$. It would be interesting to explore whether a relationship exists between neuronal activity, plasticity and memory, and plasticity at the level of the genome. Excitingly, it was recently shown that early life experiences can indeed influence DNA in the brains of rodents [12, 120].

Regardless, given the role that DNA damage plays in mutation accumulation, DNA repair must be a powerful modifier of mutagenesis as well [83, 87, 88, 105, 115]. It is conceivable for example, that an age-related loss of DNA repair efficiency (potentially due to mutations in genes encoding DNA repair proteins) could contribute to an increase in genomic instability during aging [27]. It should be noted though that mutations also occur on pristine DNA templates. For example, differences in microsatellite repeat length (a highly prevalent somatic mutation) can be caused by DNA polymerase slippage during replication. Similar replication slippage events occur on poly(A) tracts after somatic long interspersed nuclear element 1 (L1) retrotransposition events.
Mutations may also arise due to unexpected events. For example, proteins that are part of the V(D)J site-specific recombination machinery, such as recombination activating gene-1 (RAG-1), have long been known to be present in neurons [28]. This observation raises the possibility that similarities may exist between the mechanism of recombination and somatic hypermutation in B cells of the immune system and somatic mutations in neurons [33, 40]. How these mutations might affect cellular function is largely unknown. It is likely though, that because each type of mutation has a unique signature, individual mutations may affect neuronal function in unique ways. For example, copy-number variations (CNVs) can result in changes in protein synthesis [23], and endogenous retroelements (such as L1) can disrupt genes or gene regulatory elements $[10,29,37,43,45$, 93, 117, 129]. These alterations in gene expression could have very pronounced effects on neuronal function, e.g. via transdifferentiation of cells to other phenotypes (phenotypic switching) or by altering the wiring of the nervous system. As a result, somatic mutations could progressively alter the behavior of individual neurons and the neural networks they support. For example, the slow accumulation of mutations over time could explain why the first signs of neurodegeneration appear decades before behavioral signs of AD pathology appear [16]. However, the impact of post-mitotic mutations on diverse neuronal subtypes may be greater than expected based on genes alone: distinct types of neurons show differential gene expression, expression of noncoding elements, patterns of splicing and post-translational modifications of their proteins. Therefore, similar post-mitotic mutation events, potentially interacting with every aspect of cell biology, may have very broad phenotypic consequences in different neurons.

Accurate assessment of somatic mutation accumulation rates in different cell types, tissues, brain regions and species, under different conditions, remains a major challenge in the field. Different aspects of sequencing approaches, bioinformatic analyses, and validation methods can lead to artifacts that are erroneously identified as somatic mutation events [44, 70, 131, 145]. Therefore, it can be difficult to accurately calculate the mutation load of human neurons. However, a reasonable estimate of the mutation frequency in the healthy human brain suggests though that single neurons harbor approximately 800-2000 single-nucleotide variants (SNVs); $80 \%$ of these SNVs are C > T transitions [76]. In addition, approximately $13-41 \%$ of human frontal cortex neurons contain at least one megabase-sized de novo CNV [84]. Technical improvements will undoubtedly contribute to improved estimates of mutation rates, assist in filtering out false positives/noise from genuine somatic mutations, and thereby result in new insights into their etiology and importance. 


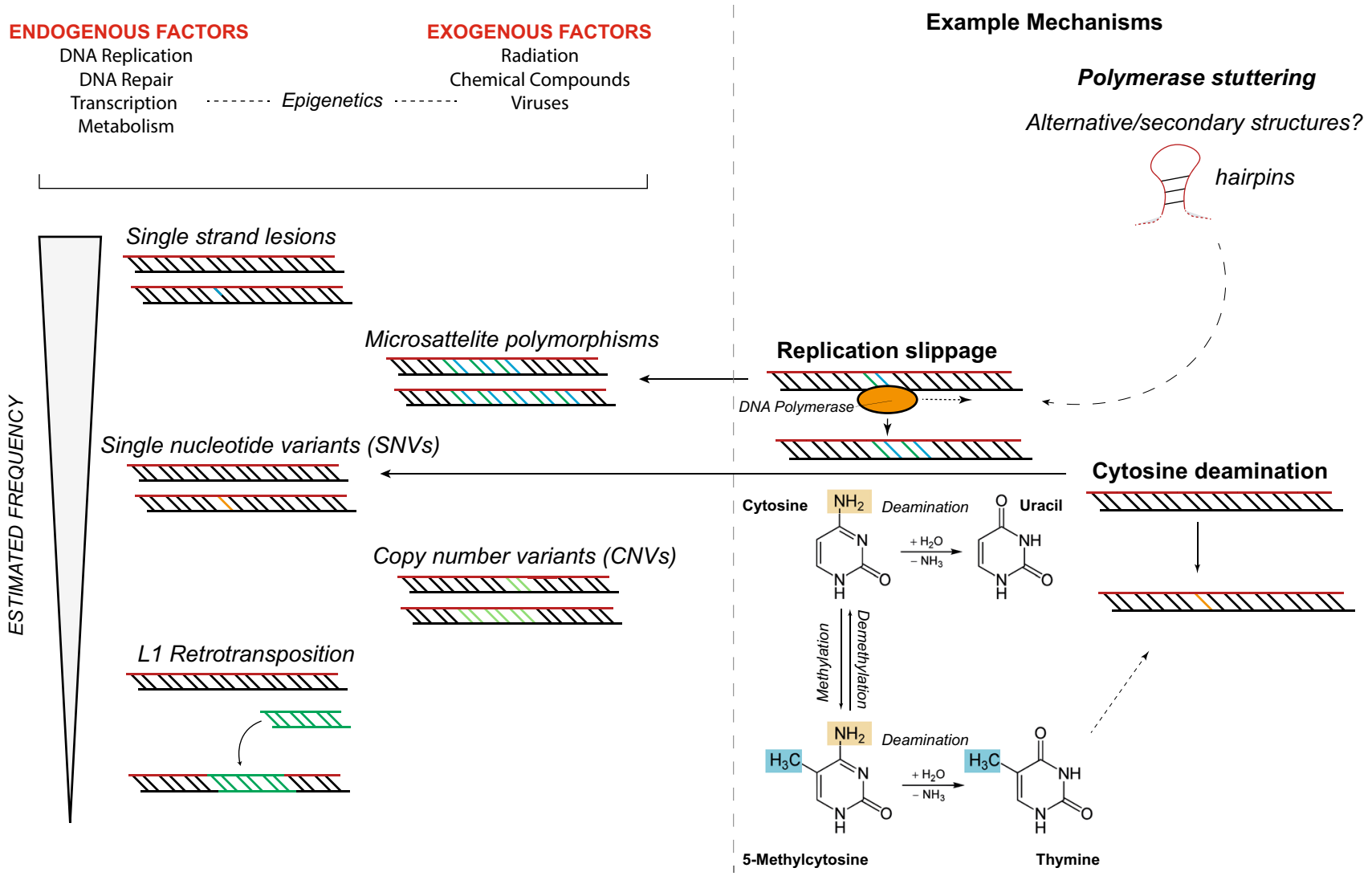

Fig. 3 Various types and mechanisms of neuronal somatic mutations. Different types of mutations have been found to be present in single neurons, including long interspersed nuclear element 1 (L1 or LINE1) retrotransposition, copy-number variations (CNVs), singlenucleotide variants (SNVs), and microsatellite/short tandem repeat variants. The exact contribution of each of these events to somatic neuronal mosaicism is unknown. Also, the mechanisms through which these mutations can arise are mostly unknown. Slippage of

\section{Somatic mutations in neurological disorders}

Somatic mutations in neurons have been demonstrated to be involved in several neuronal (developmental) disorders. For example, cancers of the nervous system have long been associated with somatic mutations. However, it is now clear that the link between somatic mutations and disease is not limited to cancer $[20,70,79,85,100,116]$.

An example of a neurodevelopmental disorder that can be caused by somatic mutations is focal cortical dysplasia (FCD), which is a cause of epilepsy. Mutations in components of the mammalian target of rapamycin (mTOR) pathway are one cause of FCD, and mTOR pathwayrelated changes in brain (micro)circuitry are likely to cause seizures [31,73]. Of course, somatic mutations and somatic brain mosaicism could cause many other neurological disorders as well, or predispose individuals to the development of these diseases. Key examples include
DNA polymerases, e.g., due to secondary structures in the chromatin, can cause changes in length of microsatellites. Cytosine deamination has been recognized as a frequent cause of SNVs. It will be necessary to accurately quantify these different types of mutations, for various cell types and brain regions, during different developmental stages or under particular conditions, in order to gain insight into their (potential) roles

developmental disorders such as autism [85], or diseases with an age-related component, such as $\mathrm{AD}[6,11,21,51$, 92, 111], Parkinson's disease [102, 103], prion disease [3], and amyotrophic lateral sclerosis (ALS) $[69,86]$ (Table 1). Strikingly, somatic mutations do not even need to occur in neuronal cells to cause neuropathology [82]. Similar to cancer, it has been speculated that the occurrence of these age-related neurological disorders may be explained by a "multiple-hit" model, a combination of developmental predisposition and somatic mutagenesis. Somatic mosaicism and age-related somatic mutations could explain for at least a number of (early-onset) sporadic (non-familial) cases [22]. However, this hypothesis could also apply to a number of other neurological disorders, like schizophrenia, semantic dementia, and a broad range of neurological phenotypes that are characterized by intellectual disability. Intriguingly, the random nature of somatic mosaicism 
Table 1 Evidence for somatic mutations in neurodegenerative disease

\begin{tabular}{|c|c|c|c|c|c|c|}
\hline Disease & $N$ (cases) & Gene(s) & Type of mutation & Approximate level (\%) & Approach & References \\
\hline \multirow[t]{3}{*}{$\mathrm{AD}$} & 1 & PS1 & SNV & 14 & PCR, ASOH, Sanger sequencing & [11] \\
\hline & 32 & $A P P$ & $\mathrm{CNV}$ & [single-cell] & Single-cell qPCR, FISH & {$[21]$} \\
\hline & 72 & $\begin{array}{l}A P P, P S 1, \\
\quad P S 2, M A P T\end{array}$ & $\mathrm{CNV}, \mathrm{SNV}$ & $\geq 10(\mathrm{CNV}), \geq 1(\mathrm{SNV})$ & Targeted deep sequencing, qPCR & [111] \\
\hline PD/DLB & 567 & $S N C A$ & SNV & $\geq 5-10$ & PCR (HRM) & {$[102,103]$} \\
\hline Prion disease & 1 & PRNP & SNV & 97 & PCR, Sanger sequencing, qPCR & [3] \\
\hline
\end{tabular}

$A D$ Alzheimer's disease, $A P P$ amyloid precursor protein, $A S O H$ allele-specific oligonucleotide hybridization, $C N V$ copy-number variations, $D L B$ dementia with Lewy bodies, FISH fluorescent in situ hybridization, HRM high resolution melt analysis, MAPT tau protein, $P C R$ polymerase chain reaction, $P D$ Parkinson's disease, $P R N P$ prion protein, $P S 1$ presenilin 1, $P S 2$ presenilin 2, $q P C R$ quantitative PCR, $S N C A$ alpha-synuclein, $S N V$ single-nucleotide variant

Partially based on [70]

could also be a factor explaining disease discordance in monozygotic twins [13].

As pointed out before, there is a fundamental difference between the clonal somatic mosaicism that is generated during neuronal development (Fig. 4a) and somatic mutations that arise in post-mitotic neurons (Fig. 4b).

Interestingly, in mosaic Down syndrome, wherein only some cells show trisomy 21, the degree of mosaicism (percentage of trisomic cells) is associated with disease severity [97]. The same holds true for other diseases with large structural abnormalities (e.g., aneuploidy, chromothripsis). Though it may seem strange, normal brains contain a certain amount of "constitutive" aneuploidy [61, 107]. Genomic duplication can also cause AD [110, 119]. For post-mitotic mutations that initiate disease, it is to be expected that a certain cascade of events occurs that ultimately results in pathology. For example, it is conceivable that some mutations in single neurons could give rise to aberrant proteins with prion-like properties that spread to other areas of the nervous system to induce disease there ("seeding") [1, 18]. Although the concept of somatic mutation-induced prionlike spreading is purely hypothetical as of now, the potential implications are enormous: elegant transplantation experiments of human stem cell-derived cortical neuronal precursors into brain of murine AD model induced hallmarks of $\mathrm{AD}$ in these human neurons, consistent with disease spread via neighboring cells [38].

In a recent single-cell whole-genome sequencing study, different somatic single-nucleotide variant ( $\mathrm{SSNV}$ ) mutational signatures were identified in single post-mitotic neurons [75]. sSNVs were found to increase approximately linearly with age ("genosenium"), with different mutation rates in different brain areas, and were more abundant (up to $\sim 2.5$-fold higher) in early-onset neurodegenerative diseases caused by defective DNA repair (i.e., Cockayne syndrome or Xeroderma pigmentosum, diseases that are characterized by defective nucleotide excision repair) (Fig. 4c). This is an interesting observation, because mutations in some other neurodegenerative diseases, such as ALS, are known to affect DNA repair as well [142]. Another interesting possibility is that disease-associated pathogenic proteins may promote mutations in neurons overall $[8,124]$, or could awaken dormant genetic elements with pathogenic properties [71].

Specifically, at least 3 different mutational signatures have been identified in brain [75]:

- Signature A, or a "clock-like" signature [2], composed mostly of $\mathrm{C}>\mathrm{T}$ and $\mathrm{T}>\mathrm{C}$ mutations and the only signature to increase with age, regardless of brain region or disease state.

- Signature B, a "neurodevelopment" signature, consisting primarily of $\mathrm{C}>\mathrm{T}$ mutations that do not correlate with age, hinting at a mutational mechanism at early ages, perhaps prenatally, and associated with neurogenesis.

- Signature C, a "disease" signature, distinguished by the presence of $\mathrm{C}>\mathrm{A}$ variants, mutations that are closely associated with oxidative DNA damage, and strongly associated disease states (i.e., neurons defective in DNA damage repair).

The existence of a "clock-like" mutational signature that shows a linear increase of somatic mutation accumulation in neurons is of particular interest, because somatic mutation accumulation/genomic instability has been suggested as a mechanism of (neuronal) aging itself [27, 126, 141]. Interestingly, $C>T$ mutations are the most abundant substitutions induced by oxidative DNA damage. Typically, these mutations are caused by oxidized cytosines that are initially converted into 5-hydroxycytosine and then metabolized further into 5-hydroxyuracil and uracil glycol [63]. Possibly then, this signature is caused by the highly metabolic nature of neurons, and the reactive oxygen species that tend to leak out of mitochondria. Accordingly, overexpression of a mitochondrially targeted catalase prevents the accumulation of $\mathrm{C}>\mathrm{T}$ mutations in 


\section{Neuronal somatic mutations and neurological disorders}

a Clonal mosaicism for disease-causing mutations

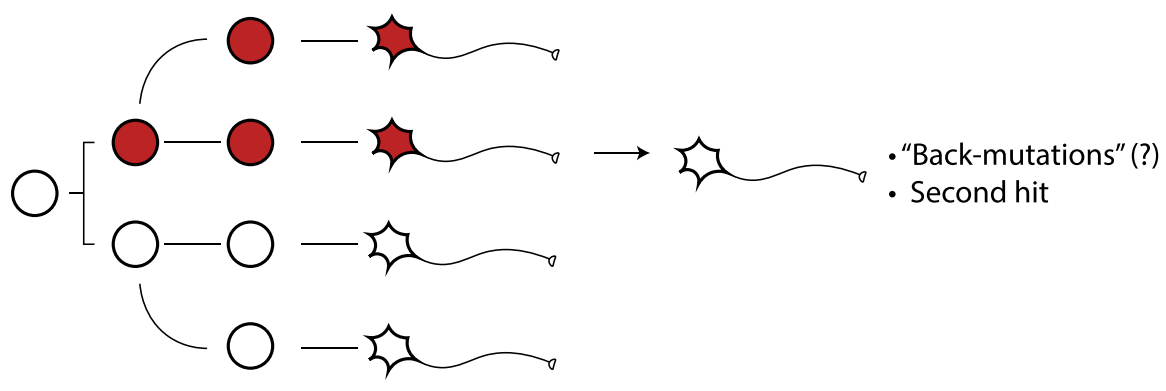

b

Post-mitotic mutations in adult neurons

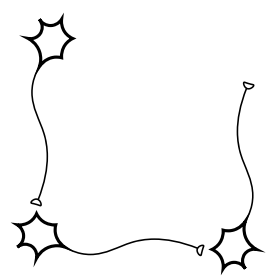

c

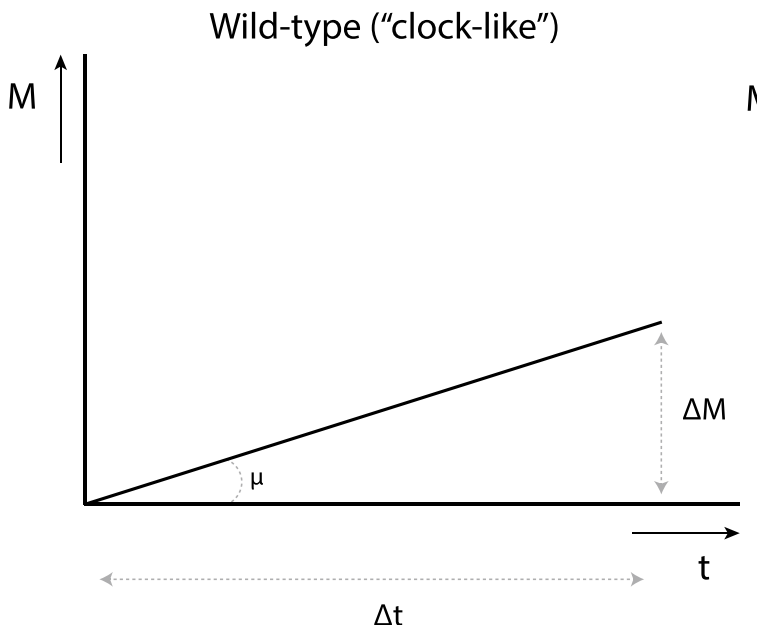

$\Delta \mathrm{t}$

Fig. 4 Neuronal somatic mutations and neurological disorders. Somatic mutations in neurons could cause or predispose for neuronal diseases. Neuronal somatic mutations can either occur in neuronal progenitors, giving rise to mutant daughter cells through clonal expansion of these mutation-carrying cells (a) or in post-mitotic neurons (b), resulting in very fine changes in the nervous system. A combination of both might reflect an intriguing mechanistic link between developmental and degenerative brain disorders. Neuron-to-neuron spreading of pathological proteins could provide an explanation for

the mitochondrial DNA of aging mouse brains [139]. In combination with signature $\mathrm{C}$, these observations suggest that oxidative damage is a primary cause of somatic mutations in neuronal cells. As a result, it might be interesting to measure somatic mutation load in cohorts that appear

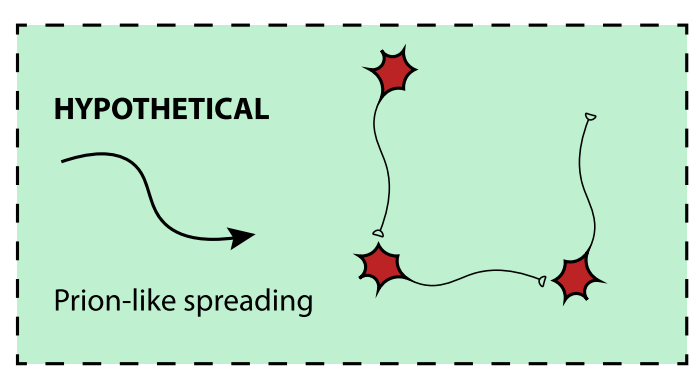

Progeroid

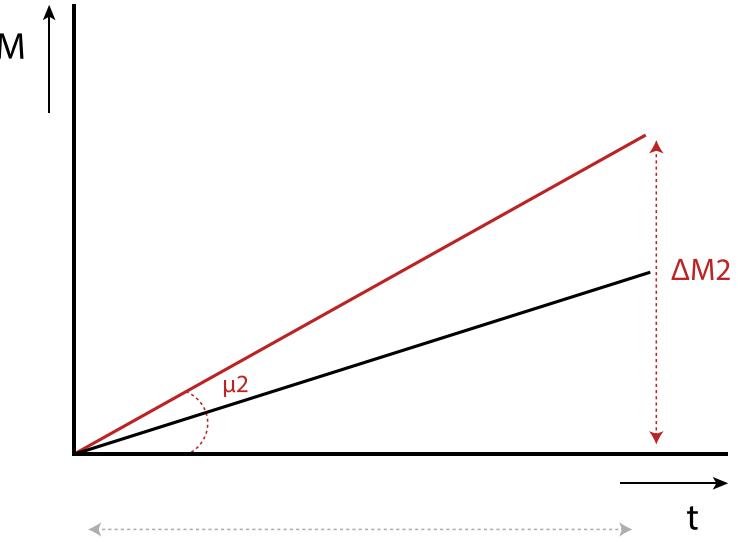

$\Delta \mathrm{t}$

widespread pathology induced by single-neuron DNA mutations, but this model is purely hypothetical as of now. c Somatic mutations have been found to accumulate in neurons as a function of age. Neuronal somatic mutation accumulation could be a general hallmark of neuronal aging. In DNA repair disorders (Cockayne syndrome, Xeroderma pigmentosum) increased rates of somatic mutations $(\mu)$ have been observed ("progeroid" phenotype). Increased rates of somatic mutation in single neurons could be important for other neurodegenerative disorders and may also accelerate neuronal aging itself

to age differently from the general population, such as (super)centenarians [49], and to monitor their anti-oxidant defenses. The potential significance of neuronal somatic mutations to disease, perhaps contributing to all sporadic disease cases, will be a strong incentive for future studies 
to explore their occurrence and phenotypic effects in more detail.

\section{Future directions}

\section{Technical aspects}

Despite a number of conceptual and technological breakthroughs, the presence of somatic mutations in neurons remains an enigmatic phenomenon. To solve this riddle, future research should focus on developing an even greater catalogue of somatic mutations in adult neurons. Early experimental models, such as the LacZ-plasmid reporter mouse model (or: "in vivo Ames test") introduced by Vijg et al., provided important insights into mutations in single cells $[14,54]$. However, such reporter loci cannot be used as a representative measure for spontaneous mutation rates in the whole genome. To study somatic mutagenesis throughout the genome, it will be critical to select the correct next-gen sequencing techniques. Recently, deep exome sequencing of DNA derived from bulk brain tissue has emerged as a valid technique for detecting somatic mutations, because it minimizes sequencing artifacts that confound downstream analyses. However, we expect that so-called duplex sequencing technology holds the greatest promise for the detection of somatic mutations in human tissues [56, 112]. This technique hinges on a clever barcoding strategy that circumvents most of the problems that plague mutation discovery to this day. An important drawback of both of these sequencing techniques though is that somatic mutations that occur in post-mitotic neurons are specific to single cells and can therefore only be conclusively identified through single-cell genome comparisons [34, 75, 85]. Therefore, a combination of single cell and next-gen sequencing technology may be required to solve these problems definitively. We expect that by leveraging this new technology, and further developing existing techniques, mutational patterns will undoubtedly emerge that will help explain the molecular mechanisms that underlie somatic brain mosaicism. Accurate mapping of somatic mutations in single neurons is technically challenging though, and it is therefore likely that technology development will remain a very important goal of the field in the foreseeable future. For example, the low amounts of genomic material that can be collected from individual cells require an initial amplification-step. In vitro nucleic acid amplification methods such as PCR are known to be error-prone, which could contribute to a faulty interpretation of sequencing results. An interesting solution to this problem is the transplantation of nuclei from post-mitotic olfactory bulb neurons to enucleated oocytes, which allows the endogenous replication machinery to amplify the genetic material. Through this method, hundreds of mutations were recently identified in clonally expanded neurons from mice [58]. Although this approach may provide a more precise estimation of the mutational profile in these cells, it is limited by its technically challenging and time-consuming nature. Thus, further improvements in single-cell sequencing techniques [50] would greatly benefit our understanding of somatic brain mosaicism.

Ideally, these improvements would be coupled to advanced microscopy techniques that can delineate the architecture of the brain in unprecedented detail [4], in combination with better tissue clearing $[5,109]$ so that the structural and temporal aspects of brain organization can be compared directly to the timing and development of somatic brain mosaicism. The use of advanced microscopy techniques would also limit confusion caused by sampling variations in the current literature, by allowing researchers from different labs to sample the exact same cells from the exact same brain areas with a greater degree of accuracy. The improved accuracy of these experiments would also allow a greater number of cells to be collected and analyzed, further removing additional sampling biases. And finally, by improving the bioinformatic pipelines that are used for the analysis of these cells, it will be possible to better interpret these complex datasets $[48,75,85]$.

However, sequencing is only a starting point for new experiments $[17,106]$. In the future, it will be equally important to elucidate the downstream effects of somatic mutations on neuronal function. For example, in situ gene editing, via in utero electroporation of gene editing constructs or local delivery of engineered ribonucleoprotein complexes $[72,85,122]$ could be a powerful method to unravel the functional consequences of genomic variability in neurons. The search for phenotypes will surely be aided by improvements in in vivo physiology approaches. We anticipate that smaller animal models will also be a powerful tool to understand the impact of somatic mutations on neuronal function. For example, exploring the effects of neuronal somatic mutations on the nervous system of $C$. elegans would be especially exciting, because the wiring diagram of the nervous system of these worms is well-characterized. Human experimental models, such as stem cell-derived neurons and cerebral organoids, would also be a valuable tool to better understand the non-uniform genomic organization of the nervous system [7, 26, 32, 67, 68, 80, 104, 113] (Fig. 5). In vitro aging of single neurons and modeling neurodevelopment in 3-dimensional cultures will enable exquisite control over experimental conditions. It would be very interesting to measure the somatic mutation load in different types of organoid cultures, to compare tissue-type specific 


\section{in vitro neuronal culture}

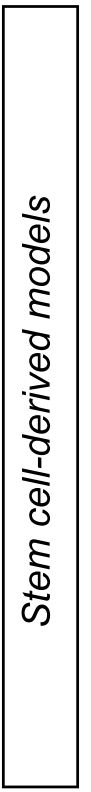

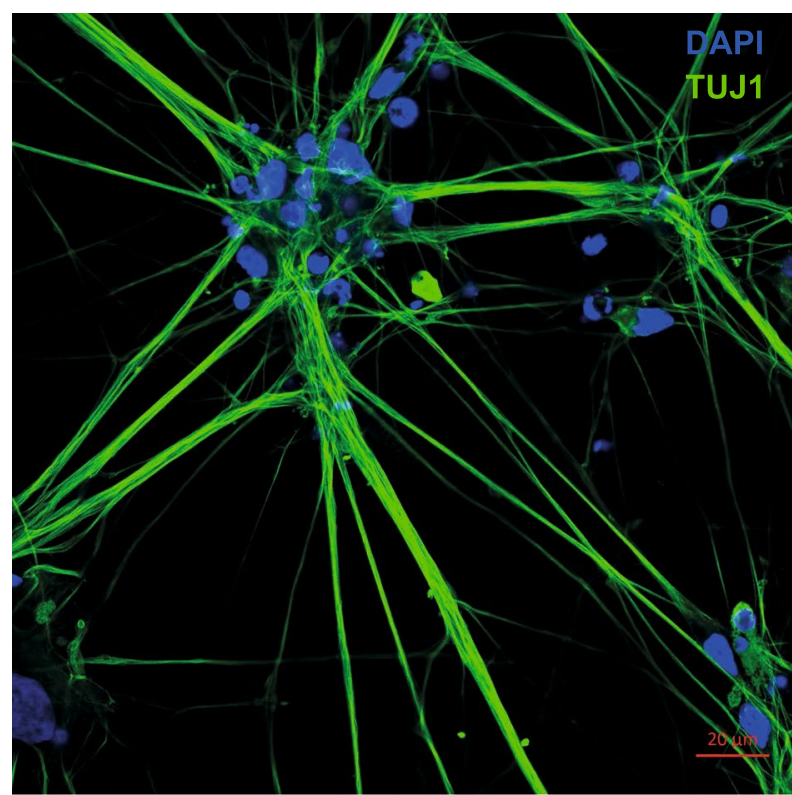

In utero electroporation (IUE)

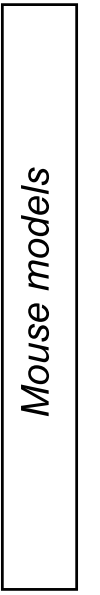

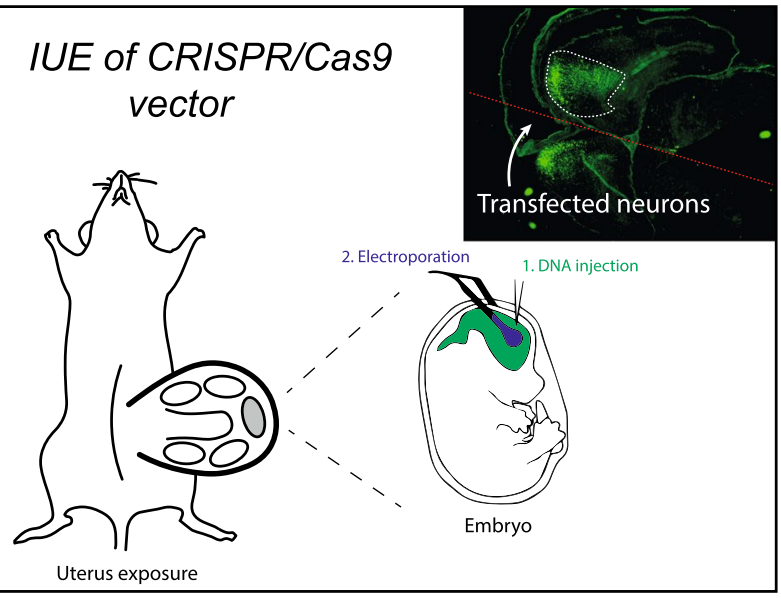

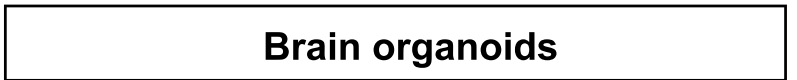

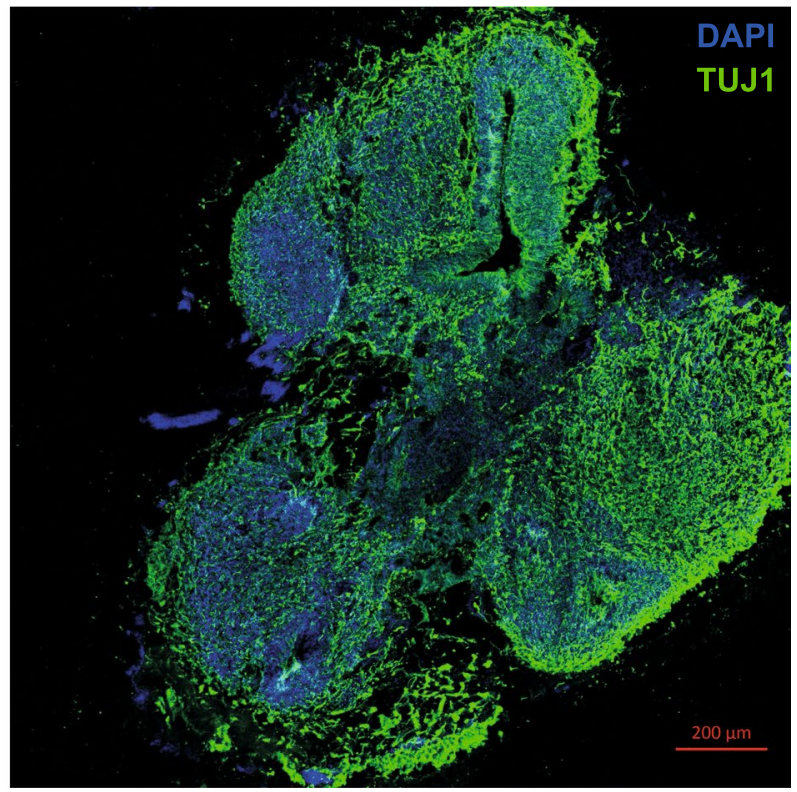

Transgenics

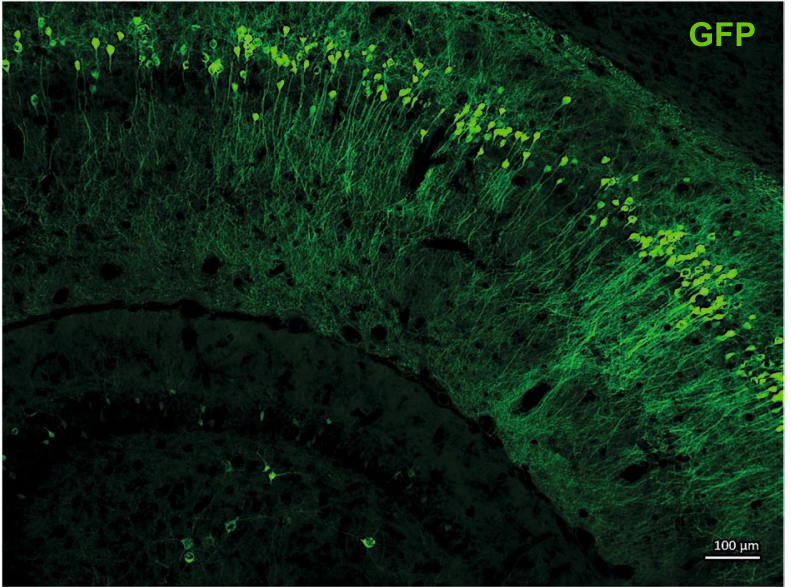

Fig. 5 Experimental strategies to model brain somatic mosaicism. Different experimental model systems can be used to mimic somatic mosaicism in the nervous system. For in vitro study of neuronal somatic mutations, hiPSC-derived neurons would be an attractive option, because they are human cells and can be derived from little starting material (through clonal expansion). Brain organoids are 3-dimensional models for neuronal brain development and disease. These also allow grafting of single neurons and grafting into live brains or other parts of organoids (e.g., to study mechanisms of prionlike spreading). Manipulated organoids can be optically cleared and imaged in 3D, e.g., using light sheet microscopy. Depending on the

mutation rates [59] and species differences [90]. Neural circuits disrupted by somatic mutation can be further studied experimentally using a battery of tests, including (2-photon) calcium imaging [147] and multi-electrode biological questions being posed, and especially the window of time and spatial requirements, different approaches can be considered. To study the in vivo contribution of somatic mutations, gene-editing constructs can be transfected in developing mouse brain via in utero electroporation of embryonic mice. Electroporation of a mouse brain (or organoid) will result in mosaic expression by default, because only select cells are transfected. In the adult brain, delivery of gene-editing ribonucleoprotein complexes (RNPs) or viral agents can be considered. Alternatively, (inducible) transgenic mice can be used to generate mosaics (Verheijen, Vermulst and van Leeuwen, unpublished)

arrays [121] or optogenetic approaches [89, 118], to analyze networks. Transcriptomics, proteomics, and metabolic profiling can be used to further explore the effects of mutations on gene expression and metabolite 
a

Molecular Misreading

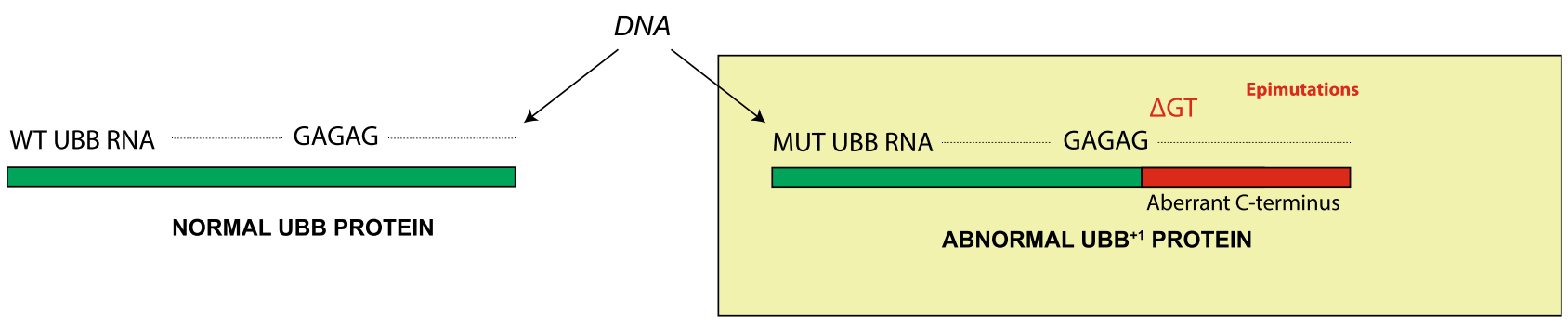

b

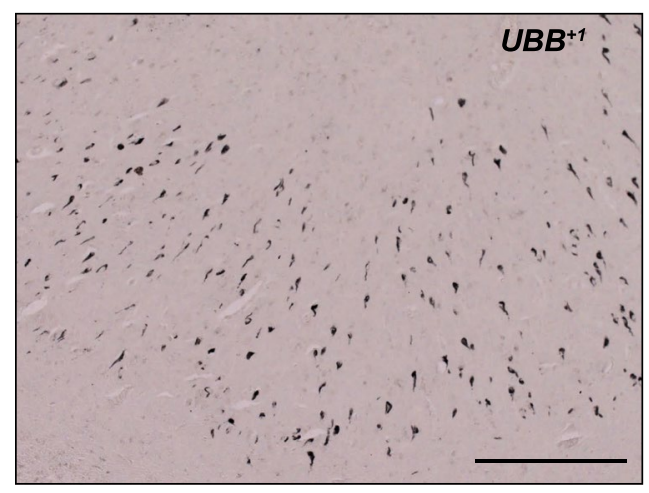

C

$\mathrm{UBB}^{+1}$
anti-Ubi3 antibody

YADLREDPDRQDHHPGSGAQ

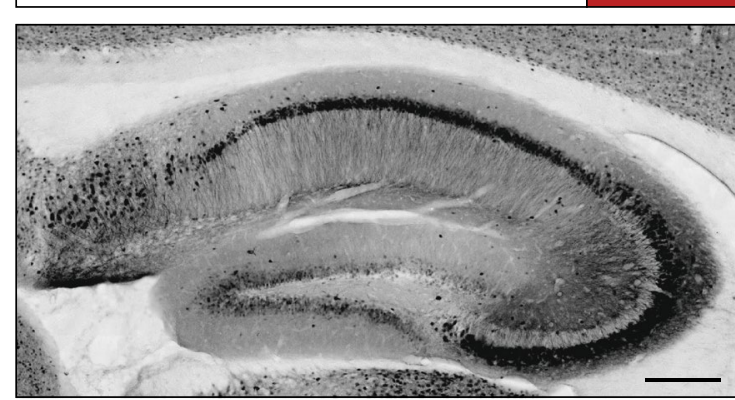

$\mathrm{UBB}^{+1} \operatorname{tg}$ mouse

Fig. 6 Neuronal epimutations. a Schematic representation of "molecular misreading", a form of transcriptional mutagenesis or "epimutation". (Epi)genomic drift and an overall increase in transcriptional noise may contribute to age-related neurodegenerative processes. Dinucleotide deletions (e.g., $\Delta \mathrm{GA}$ or $\Delta \mathrm{GU}$ ) in an mRNA molecule can result in the generation of mutant proteins, which can be recognized by specific antibodies. b An example of such a mutant protein is ubiquitin- $\mathrm{B}^{+1}\left(\mathrm{UBB}^{+1}\right) . \mathrm{UBB}^{+1}$ is detectable in the brains of Alzheimer's disease (AD) patient brains, by immunocytochemistry

fingerprints, but particular phenotypes associated with specific mutations and diseases will probably require specialized (biochemical) assays.

Finally, it will also be important to carry out neuropathological examinations to validate findings related to brain mosaicism. (Single-cell) DNA sequencing will be the main approach to identify somatic mutations in neurons, but checking these findings against the reality of human tissues will be crucial to avoid errors introduced by technical artifacts. In situ hybridization using probes that specifically recognize abnormal gene products would be a straightforward method to look for abnormalities in single cells. Antibodies that specifically recognize certain mutant proteins have also been utilized for this purpose in the past $[39,134]$. Combining this information with other neuropathological indicators, like abnormal cellular morphology and cellular stress markers, could also be a means to link somatic mutations to disease processes. using antibodies that specifically recognize the abnormal C-terminal domain of $\mathrm{UBB}^{+1}$. This demonstrates the importance of neuropathological observation in validating these mutational events. Scale bar: $200 \mu \mathrm{m}$. c Transgenic expression of $\mathrm{UBB}^{+1}$ in mice results in behavioral phenotypes that are consistent with neurodegeneration. Image shows a sagittal section of the hippocampus of a $\mathrm{UBB}^{+1}$ transgenic mouse, stained for $\mathrm{UBB}^{+1}$. Scale bar: $200 \mu \mathrm{m}$ (Verheijen, Vermulst and van Leeuwen, unpublished)

\section{Beyond the genome: neuronal epimutations}

Until now, most of the work on somatic brain mosaicism has focused on genetic changes in DNA (including mitochondrial DNA [25]). It is possible though that non-genetic changes play a role in brain mosaicism as well. After all, the damage that is thought to be responsible for the accumulation of genetic mutations in aging neurons (e.g., oxidative and mechanical damage) also affects other cellular processes. For example, certain DNA lesions reduce the fidelity of RNA polymerase II, which provokes transcription errors, or so-called epimutations, in neuronal cells [114]. It is now clear that despite their transient nature, these transcriptional noise events may result in robust phenotypic changes and disease $[53,55,138,140]$.

For example, through a mechanism dubbed "molecular misreading", which describes the inaccurate conversion of DNA to RNA during transcription, frameshift mutants can arise of the ubiquitin-B (UBB) protein (i.e., $\mathrm{UBB}^{+1}$ ) $[130,133,134,136,137]$ (Fig. 6). Importantly, $\mathrm{UBB}^{+1}$ is 
an inhibitor of the ubiquitin proteasome system (UPS) and delays the targeted destruction of both normal and abnormal proteins, thereby compromising the integrity of the proteome. Interestingly, $\mathrm{UBB}^{+1}$ accumulates in the neuropathological hallmarks of Alzheimer's disease (AD) and several other disorders [52], and by inhibiting the UPS, $\mathrm{UBB}^{+1}$ is thought to promote the aggregation of toxic peptides that play a role in disease progression.

Programs for the modification of DNA and 3D chromatin $[47,64,78,91,95,128]$, RNA and proteins, such as RNA modification [149], protein conformational conversion [57], and post-translational modifications add another layer of complexity to these phenomena. For example, RNA editing is specifically enriched in the nervous system of behaviorally sophisticated coleoid cephalopods, affecting molecules that are essential for the morphology and excitability of neuronal cells [74]. With the introduction of new RNA-targeting tools $[146,30]$, it may now be possible to study these events in unprecedented detail. However, we are only beginning to explore the origins and downstream consequences of non-genetic mutations in the nervous system. But with improved detection techniques, and a better understanding of their physiological consequences, these observations could greatly enrich our understanding of somatic brain mosaicisms (as well as mosaicisms in other tissues [35, 125]) and ultimately contribute to better diagnoses and treatments with next generation, personalized drugs.

Acknowledgements We apologize to the authors of numerous excellent papers that could not be cited or discussed here due to space limitations. Images in Fig. 5 were obtained by B.M.V. in the lab of Prof. Dr. R.J. Pasterkamp (MIND Facility, Brain Center Rudolf Magnus, Utrecht, The Netherlands). F.W.v.L. received funding from Internationale Stichting Alzheimer Onderzoek (ISAO), Hersenstichting Nederland, International Parkinson Foundation (IPF), and Van Leersum KNAW Foundation.

Author contributions All authors listed have made a substantial, direct, and intellectual contribution to the work, and approved it for publication.

\section{Compliance with ethical standards}

Conflict of interest The authors declare that the research was conducted in the absence of any commercial or financial relationships that could be construed as a potential conflict of interest.

Open Access This article is distributed under the terms of the Creative Commons Attribution 4.0 International License (http://creativeco mmons.org/licenses/by/4.0/), which permits unrestricted use, distribution, and reproduction in any medium, provided you give appropriate credit to the original author(s) and the source, provide a link to the Creative Commons license, and indicate if changes were made.

\section{References}

1. Aguzzi A, Lakkaraju AKK (2016) Cell biology of prions and prionoids: a status report. Trends Cell Biol 26:40-51. https://doi. org/10.1016/j.tcb.2015.08.007

2. Alexandrov LB, Jones PH, Wedge DC, Sale JE, Campbell PJ, Nik-Zainal S et al (2015) Clock-like mutational processes in human somatic cells. Nat Genet 47:1402-1407. https://doi. org/10.1038/ng.3441

3. Alzualde A, Moreno F, Martínez-Lage P, Ferrer I, Gorostidi A, Otaegui D et al (2010) Somatic mosaicism in a case of apparently sporadic Creutzfeldt-Jakob disease carrying a de novo D178 N mutation in the PRNP gene. Am J Med Genet B Neuropsychiatr Genet 153B:1283-1291. https://doi.org/10.1002/ ajmg.b.31099

4. Amunts K, Zilles K (2015) Architectonic mapping of the human brain beyond brodmann. Neuron 88:1086-1107. https://doi. org/10.1016/j.neuron.2015.12.001

5. Ando K, Laborde Q, Lazar A, Godefroy D, Youssef I, Amar $M$ et al (2014) Inside Alzheimer brain with CLARITY: senile plaques, neurofibrillary tangles and axons in 3-D. Acta Neuropathol 128:457-459. https://doi.org/10.1007/s00401-014-1322-y

6. Arendt T, Brückner MK, Lösche A (2015) Regional mosaic genomic heterogeneity in the elderly and in Alzheimer's disease as a correlate of neuronal vulnerability. Acta Neuropathol 130:501-510. https://doi.org/10.1007/s00401-015-1465-5

7. Arlotta P (2018) Organoids required! A new path to understanding human brain development and disease. Nat Methods 15:2729. https://doi.org/10.1038/nmeth.4557

8. Avila J, Gómez-Ramos A, Soriano E (2014) Variations in brain DNA. Front Aging Neurosci 6:323. https://doi.org/10.3389/fnagi .2014 .00323

9. Bae T, Tomasini L, Mariani J, Zhou B, Roychowdhury T, Franjic D et al (2017) Different mutational rates and mechanisms in human cells at pregastrulation and neurogenesis. Science 543:eaan8690. https://doi.org/10.1126/science.aan8690

10. Baillie JK, Barnett MW, Upton KR, Gerhardt DJ, Richmond TA, De Sapio F et al (2011) Somatic retrotransposition alters the genetic landscape of the human brain. Nature 479:534-537. https ://doi.org/10.1038/nature 10531

11. Beck JA, Poulter M, Campbell TA, Uphill JB, Adamson G, Geddes JF et al (2004) Somatic and germline mosaicism in sporadic early-onset Alzheimer's disease. Hum Mol Genet 13:1219-1224. https://doi.org/10.1093/hmg/ddh134

12. Bedrosian TA, Quayle C, Novaresi N, Gage FH (2018) Early life experience drives structural variation of neural genomes in mice. Science 359:1395-1399. https://doi.org/10.1126/science.aah33 78

13. Biesecker LG, Spinner NB (2013) A genomic view of mosaicism and human disease. Nat Rev Genet 14:307-320. https://doi. org/10.1038/nrg3424

14. Boerrigter ME, Dollé ME, Martus HJ, Gossen JA, Vijg J (1995) Plasmid-based transgenic mouse model for studying in vivo mutations. Nature 377:657-659. https://doi.org/10.1038/37765 $7 \mathrm{a} 0$

15. Boldrini M, Fulmore CA, Tartt AN, Simeon LR, Pavlova I, Poposka V et al (2018) Human hippocampal neurogenesis persists throughout aging. Cell Stem Cell 22(589-599):e5. https://doi. org/10.1016/j.stem.2018.03.015

16. Braak H, Del Tredici K (2012) Where, when, and in what form does sporadic Alzheimer's disease begin? Curr Opin Neurol 25:708-714. https://doi.org/10.1097/WCO.0b013e32835a3432

17. Brenner S (2010) Sequences and consequences. Philos Trans R Soc Lond B Biol Sci 365:207-212. https://doi.org/10.1098/ rstb.2009.0221 
18. Brettschneider J, Del Tredici K, Lee VM-Y, Trojanowski JQ (2015) Spreading of pathology in neurodegenerative diseases: a focus on human studies. Nat Rev Neurosci 16:109-120. https:// doi.org/10.1038/nrn3887

19. Burbach JP, Luckman SM, Murphy D, Gainer H (2001) Gene regulation in the magnocellular hypothalamo-neurohypophysial system. Physiol Rev 81:1197-1267

20. Bushman DM, Chun J (2013) The genomically mosaic brain: aneuploidy and more in neural diversity and disease. Semin Cell Dev Biol 24:357-369. https://doi.org/10.1016/j.semcd b.2013.02.003

21. Bushman DM, Kaeser GE, Siddoway B, Westra JW, Rivera RR, Rehen SK et al (2015) Genomic mosaicism with increased amyloid precursor protein (APP) gene copy number in single neurons from sporadic Alzheimer's disease brains. Elife 4:208. https:// doi.org/10.7554/eLife.05116

22. Cacace R, Sleegers K, Van Broeckhoven C (2016) Molecular genetics of early-onset Alzheimer's disease revisited. Alzheimers Dement 12:733-748. https://doi.org/10.1016/j.jalz.2016.01.012

23. Cai X, Evrony GD, Lehmann HS, Elhosary PC, Mehta BK, Poduri A et al (2014) Single-cell, genome-wide sequencing identifies clonal somatic copy-number variation in the human brain. Cell Rep 8:1280-1289. https://doi.org/10.1016/j.celre p.2014.07.043

24. Campbell IM, Shaw CA, Stankiewicz P, Lupski JR (2015) Somatic mosaicism: implications for disease and transmission genetics. Trends Genet 31:382-392. https://doi.org/10.1016/j. tig.2015.03.013

25. Cantuti-Castelvetri I, Lin MT, Zheng K, Keller-McGandy CE, Betensky RA, Johns DR et al (2005) Somatic mitochondrial DNA mutations in single neurons and glia. Neurobiol Aging 26:13431355. https://doi.org/10.1016/j.neurobiolaging.2004.11.008

26. Choi SH, Kim YH, Hebisch M, Sliwinski C, Lee S, D’Avanzo $\mathrm{C}$ et al (2014) A three-dimensional human neural cell culture model of Alzheimer's disease. Nature 515:274-278. https://doi. org/10.1038/nature 13800

27. Chow H-M, Herrup K (2015) Genomic integrity and the ageing brain. Nat Rev Neurosci 16:672-684. https://doi.org/10.1038/ nrn 4020

28. Chun JJ, Schatz DG, Oettinger MA, Jaenisch R, Baltimore D (1991) The recombination activating gene-1 (RAG-1) transcript is present in the murine central nervous system. Cell 64:189-200. https://doi.org/10.1016/0092-8674(91)90220-S

29. Coufal NG, Garcia-Perez JL, Peng GE, Marchetto MCN, Muotri AR, Mu Y et al (2011) Ataxia telangiectasia mutated (ATM) modulates long interspersed element-1 (L1) retrotransposition in human neural stem cells. Proc Natl Acad Sci USA 108:2038220387. https://doi.org/10.1073/pnas.1100273108

30. Cox DBT, Gootenberg JS, Abudayyeh OO, Franklin B, Kellner MJ, Joung J, et al (2017) RNA editing with CRISPR-Cas13. Science 358:1019-1027. https://doi.org/10.1126/science.aaq0180

31. D'Gama AM, Woodworth MB, Hossain AA, Bizzotto S, Hatem NE, LaCoursiere CM et al (2017) Somatic mutations activating the mTOR pathway in dorsal telencephalic progenitors cause a continuum of cortical dysplasias. Cell Rep 21:3754-3766. https ://doi.org/10.1016/j.celrep.2017.11.106

32. Di Lullo E, Kriegstein AR (2017) The use of brain organoids to investigate neural development and disease. Nat Rev Neurosci 18:573-584. https://doi.org/10.1038/nrn.2017.107

33. Di Noia JM, Neuberger MS (2007) Molecular mechanisms of antibody somatic hypermutation. Annu Rev Biochem 76:1-22. https://doi.org/10.1146/annurev.biochem.76.061705.090740

34. Dumanski JP, Piotrowski A (2012) Structural genetic variation in the context of somatic mosaicism. Methods Mol Biol 838:249272. https://doi.org/10.1007/978-1-61779-507-7_12
35. Enge M, Arda HE, Mignardi M, Beausang J, Bottino R, Kim SK et al (2017) Single-cell analysis of human pancreas reveals transcriptional signatures of aging and somatic mutation patterns. Cell 171(321-330):e14. https://doi.org/10.1016/j. cell.2017.09.004

36. Eriksson PS, Perfilieva E, Björk-Eriksson T, Alborn AM, Nordborg C, Peterson DA et al (1998) Neurogenesis in the adult human hippocampus. Nat Med 4:1313-1317. https://doi. org/10.1038/3305

37. Erwin JA, Paquola ACM, Singer T, Gallina I, Novotny M, Quayle C et al (2016) L1-associated genomic regions are deleted in somatic cells of the healthy human brain. Nat Neurosci 19:1583-1591. https://doi.org/10.1038/nn.4388

38. Espuny-Camacho I, Arranz AM, Fiers M, Snellinx A, Ando K, Munck S et al (2017) Hallmarks of Alzheimer's disease in stem-cell-derived human neurons transplanted into mouse brain. Neuron 93(1066-1081):e8. https://doi.org/10.1016/j. neuron.2017.02.001

39. Evans DA, Burbach JP, Swaab DF, van Leeuwen FW (1996) Mutant vasopressin precursors in the human hypothalamus: evidence for neuronal somatic mutations in man. Neuroscience 71:1025-1030. https://doi.org/10.1016/0306-4522(95)00501-3

40. Evans DA, Burbach JP, van Leeuwen FW (1995) Somatic mutations in the brain: relationship to aging? Mutat Res 338:173-182. https://doi.org/10.1016/0921-8734(95)00022-X

41. Evans DA, van der Kleij AA, Sonnemans MAF, Burbach JP, van Leeuwen FW (1994) Frameshift mutations at two hotspots in vasopressin transcripts in post-mitotic neurons. Proc Natl Acad Sci USA 91:6059-6063

42. Evrony GD (2016) One brain, many genomes. Science 354:557-558. https://doi.org/10.1126/science.aak9761

43. Evrony GD, Cai X, Lee E, Hills LB, Elhosary PC, Lehmann HS et al (2012) Single-neuron sequencing analysis of L1 retrotransposition and somatic mutation in the human brain. Cell 151:483-496. https://doi.org/10.1016/j.cell.2012.09.035

44. Evrony GD, Lee E, Park PJ, Walsh CA (2016) Resolving rates of mutation in the brain using single-neuron genomics. Elife 5:56. https://doi.org/10.7554/eLife.12966

45. Faulkner GJ, Garcia-Perez JL (2017) L1 mosaicism in mammals: extent, effects, and evolution. Trends Genet 33:802-816. https://doi.org/10.1016/j.tig.2017.07.004

46. Finch CE (1990) Longevity, senescence, and the genome. University of Chicago Press, Chicago

47. Fischer A, Sananbenesi F, Wang X, Dobbin M, Tsai L-H (2007) Recovery of learning and memory is associated with chromatin remodelling. Nature 447:178-182. https://doi.org/10.1038/ nature 05772

48. Frigerio CS, Fiers M, Voet T, De Strooper B (2017) Identification of low allele frequency mosaic mutations in Alzheimer disease. In: Frade JM, Gage FH (eds) Genomic mosaicism in neurons and other cell types. Springer, New York, pp 361-378

49. Ganz AB, Beker N, Hulsman M, Sikkes S, NBB, Scheltens $P$ et al (2018) Neuropathology and cognitive performance in centenarians. bioRxiv. https://doi.org/10.1101/298935

50. Gawad C, Koh W, Quake SR (2016) Single-cell genome sequencing: current state of the science. Nat Rev Genet 17:175-188. https://doi.org/10.1038/nrg.2015.16

51. Geller LN, Potter H (1999) Chromosome missegregation and trisomy 21 mosaicism in Alzheimer's disease. Neurobiol Dis 6:167-179. https://doi.org/10.1006/nbdi.1999.0236

52. Gentier RJ, van Leeuwen FW (2015) Misframed ubiquitin and impaired protein quality control: an early event in Alzheimer's disease. Front Mol Neurosci 8:47. https://doi.org/10.3389/ fnmol.2015.00047

53. Gordon AJE, Satory D, Halliday JA, Herman C (2013) Heritable change caused by transient transcription errors. PLoS 
Genet 9:e1003595. https://doi.org/10.1371/journal.pgen.10035 95

54. Gossen JA, de Leeuw WJ, Tan CH, Zwarthoff EC, Berends F, Lohman PH et al (1989) Efficient rescue of integrated shuttle vectors from transgenic mice: a model for studying mutations in vivo. Proc Natl Acad Sci USA 86:7971-7975

55. Gout J-F, Li W, Fritsch C, Li A, Haroon S, Singh L et al (2017) The landscape of transcription errors in eukaryotic cells. Sci Adv 3:e1701484. https://doi.org/10.1126/sciadv.1701484

56. Gregory MT, Bertout JA, Ericson NG, Taylor SD, Mukherjee R, Robins HS et al (2016) Targeted single molecule mutation detection with massively parallel sequencing. Nucleic Acids Res 44:e22-e22. https://doi.org/10.1093/nar/gkv915

57. Harvey ZH, Chen Y, Jarosz DF (2017) Protein-based inheritance: epigenetics beyond the chromosome. Mol Cell. https://doi. org/10.1016/j.molcel.2017.10.030

58. Hazen JL, Faust GG, Rodriguez AR, Ferguson WC, Shumilina S, Clark RA et al (2016) The complete genome sequences, unique mutational spectra, and developmental potency of adult neurons revealed by cloning. Neuron 89:1223-1236. https://doi. org/10.1016/j.neuron.2016.02.004

59. Jager M, Blokzijl F, Sasselli V, Boymans S, Janssen R, Besselink $\mathrm{N}$ et al (2018) Measuring mutation accumulation in single human adult stem cells by whole-genome sequencing of organoid cultures. Nat Protoc 13:59-78. https://doi.org/10.1038/nprot .2017.111

60. Kennedy SR, Loeb LA, Herr AJ (2012) Somatic mutations in aging, cancer and neurodegeneration. Mech Ageing Dev 133:118-126. https://doi.org/10.1016/j.mad.2011.10.009

61. Kingsbury MA, Friedman B, McConnell MJ, Rehen SK, Yang AH, Kaushal D et al (2005) Aneuploid neurons are functionally active and integrated into brain circuitry. Proc Natl Acad Sci USA 102:6143-6147. https://doi.org/10.1073/pnas.0408171102

62. Kirkwood TBL (2005) Understanding the odd science of aging. Cell 120:437-447. https://doi.org/10.1016/j.cell.2005.01.027

63. Kreutzer DA, Essigmann JM (1998) Oxidized, deaminated cytosines are a source of $\mathrm{C} \rightarrow \mathrm{T}$ transitions in vivo. Proc Natl Acad Sci USA 95:3578-3582. https://doi.org/10.1073/ pnas.95.7.3578

64. Krijger PHL, de Laat W (2016) Regulation of disease-associated gene expression in the 3D genome. Nat Rev Mol Cell Biol 17:771-782. https://doi.org/10.1038/nrm.2016.138

65. La Manno G, Gyllborg D, Codeluppi S, Nishimura K, Salto C, Zeisel A et al (2016) Molecular diversity of midbrain development in mouse, human, and stem cells. Cell 167(566-580):e19. https://doi.org/10.1016/j.cell.2016.09.027

66. Lake BB, Ai R, Kaeser GE, Salathia NS, Yung YC, Liu R et al (2016) Neuronal subtypes and diversity revealed by singlenucleus RNA sequencing of the human brain. Science 352:15861590. https://doi.org/10.1126/science.aaf1204

67. Lancaster MA, Knoblich JA (2014) Organogenesis in a dish: modeling development and disease using organoid technologies. Science 345:1247125. https://doi.org/10.1126/science.1247125

68. Lancaster MA, Renner M, Martin C-A, Wenzel D, Bicknell LS, Hurles ME et al (2013) Cerebral organoids model human brain development and microcephaly. Nature 501:373-379. https://doi. org/10.1038/nature 12517

69. Lee JH (2016) Somatic mutations in disorders with disrupted brain connectivity. Exp Mol Med 48:e239-e239. https://doi. org/10.1038/emm.2016.53

70. Leija-Salazar M, Piette C, Proukakis C (2018) Somatic mutations in neurodegeneration. Neuropathol Appl Neurobiol 3:748. https ://doi.org/10.1111/nan.12465

71. Li W, Lee M-H, Henderson L, Tyagi R, Bachani M, Steiner J et al (2015) Human endogenous retrovirus-K contributes to motor neuron disease. Sci Transl Med 7:307ra153-307ra153. https:// doi.org/10.1126/scitranslmed.aac8201

72. Lim JS, Gopalappa R, Kim SH, Ramakrishna S, Lee M, Kim W-I et al (2017) Somatic mutations in TSC1 and TSC2 cause focal cortical dysplasia. Am J Hum Genet 100:454-472. https://doi. org/10.1016/j.ajhg.2017.01.030

73. Lim JS, Kim W-I, Kang H-C, Kim SH, Park AH, Park EK et al (2015) Brain somatic mutations in MTOR cause focal cortical dysplasia type II leading to intractable epilepsy. Nat Med 21:395-400. https://doi.org/10.1038/nm.3824

74. Liscovitch-Brauer N, Alon S, Porath HT, Elstein B, Unger R, Ziv T et al (2017) Trade-off between transcriptome plasticity and genome evolution in cephalopods. Cell 169(191-202):e11. https ://doi.org/10.1016/j.cell.2017.03.025

75. Lodato MA, Rodin RE, Bohrson CL, Coulter ME, Barton AR, Kwon $\mathrm{M}$ et al (2017) Aging and neurodegeneration are associated with increased mutations in single human neurons. Science 57:eaao4426. https://doi.org/10.1126/science.aao4426

76. Lodato MA, Woodworth MB, Lee S, Evrony GD, Mehta BK, Karger A et al (2015) Somatic mutation in single human neurons tracks developmental and transcriptional history. Science 350:94-98. https://doi.org/10.1126/science.aab1785

77. López-Otín C, Blasco MA, Partridge L, Serrano M, Kroemer G (2013) The hallmarks of aging. Cell 153:1194-1217. https://doi. org/10.1016/j.cell.2013.05.039

78. Luo C, Keown CL, Kurihara L, Zhou J, He Y, Li J et al (2017) Single-cell methylomes identify neuronal subtypes and regulatory elements in mammalian cortex. Science 357:600-604. https ://doi.org/10.1126/science.aan3351

79. Madabhushi R, Pan L, Tsai L-H (2014) DNA damage and its links to neurodegeneration. Neuron 83:266-282. https://doi. org/10.1016/j.neuron.2014.06.034

80. Mansour AA, Gonçalves JT, Bloyd CW, Li H, Fernandes S, Quang D et al (2018) An in vivo model of functional and vascularized human brain organoids. Nat Biotechnol 6:114. https:// doi.org/10.1038/nbt.4127

81. Martincorena I, Campbell PJ (2015) Somatic mutation in cancer and normal cells. Science 349:1483-1489. https://doi. org/10.1126/science.aab4082

82. Mass E, Jacome-Galarza CE, Blank T, Lazarov T, Durham BH, Ozkaya $\mathrm{N}$ et al (2017) A somatic mutation in erythro-myeloid progenitors causes neurodegenerative disease. Nature 353:777. https://doi.org/10.1038/nature23672

83. Mata-Garrido J, Casafont I, Tapia O, Berciano MT, Lafarga M (2016) Neuronal accumulation of unrepaired DNA in a novel specific chromatin domain: structural, molecular and transcriptional characterization. Acta Neuropathol Commun 4:41. https ://doi.org/10.1186/s40478-016-0312-9

84. McConnell MJ, Lindberg MR, Brennand KJ, Piper JC, Voet T, Cowing-Zitron C et al (2013) Mosaic copy number variation in human neurons. Science 342:632-637. https://doi.org/10.1126/ science. 1243472

85. McConnell MJ, Moran JV, Abyzov A, Akbarian S, Bae T, CortesCiriano I et al (2017) Intersection of diverse neuronal genomes and neuropsychiatric disease: The Brain Somatic Mosaicism Network. Science 356:eaal1641. https://doi.org/10.1126/scien ce.aal1641

86. McGoldrick P, Zhang M, van Blitterswijk M, Sato C, Moreno D, Xiao $S$ et al (2018) Unaffected mosaic C9orf72 case: RNA foci, dipeptide proteins, but upregulated C9orf72 expression. Neurology 90:e323-e331. https://doi.org/10.1212/WNL.0000000000 004865

87. McKinnon PJ (2009) DNA repair deficiency and neurological disease. Nat Rev Neurosci 10:100-112. https://doi.org/10.1038/ $\operatorname{nrn} 2559$ 
88. McKinnon PJ (2013) Maintaining genome stability in the nervous system. Nat Neurosci 16:1523-1529. https://doi.org/10.1038/ nn.3537

89. Miesenböck G (2011) Optogenetic control of cells and circuits. Annu Rev Cell Dev Biol 27:731-758. https://doi.org/10.1146/ annurev-cellbio-100109-104051

90. Milholland B, Dong X, Zhang L, Hao X, Suh Y, Vijg J (2017) Differences between germline and somatic mutation rates in humans and mice. Nat Commun 8:15183. https://doi. org/10.1038/ncomms 15183

91. Misteli T, Soutoglou E (2009) The emerging role of nuclear architecture in DNA repair and genome maintenance. Nat Rev Mol Cell Biol 10:243-254. https://doi.org/10.1038/nrm2651

92. Mullaart E, Boerrigter METI, Ravid R, Swaab DF, Vijg J (1990) Increased levels of DNA breaks in cerebral cortex of Alzheimer's disease patients. Neurobiol Aging 11:169-173. https://doi. org/10.1016/0197-4580(90)90542-8

93. Muotri AR, Chu VT, Marchetto MCN, Deng W, Moran JV, Gage FH (2005) Somatic mosaicism in neuronal precursor cells mediated by L1 retrotransposition. Nature 435:903-910. https://doi. org/10.1038/nature03663

94. Muotri AR, Gage FH (2006) Generation of neuronal variability and complexity. Nature 441:1087-1093. https://doi.org/10.1038/ nature 04959

95. Nativio R, Donahue G, Berson A, Lan Y, Amlie-Wolf A, Tuzer F et al (2018) Dysregulation of the epigenetic landscape of normal aging in Alzheimer's disease. Nat Neurosci 21:497-505. https:// doi.org/10.1038/s41593-018-0101-9

96. Ofengeim D, Giagtzoglou N, Huh D, Zou C, Yuan J (2017) Single-cell RNA sequencing: unraveling the brain one cell at a time. Trends Mol Med 23:563-576. https://doi.org/10.1016/j.molme d.2017.04.006

97. Papavassiliou P, York TP, Gursoy N, Hill G, Nicely LV, Sundaram U et al (2009) The phenotype of persons having mosaicism for trisomy 21/Down syndrome reflects the percentage of trisomic cells present in different tissues. Am J Med Genet A 149A:573-583. https://doi.org/10.1002/ajmg.a.32729

98. Paquola ACM, Erwin JA, Gage FH (2017) Insights into the role of somatic mosaicism in the brain. Curr Opin Syst Biol 1:90-94. https://doi.org/10.1016/j.coisb.2016.12.004

99. Perera F, Herbstman J (2011) Prenatal environmental exposures, epigenetics, and disease. Reprod Toxicol 31:363-373. https://doi. org/10.1016/j.reprotox.2010.12.055

100. Poduri A, Evrony GD, Cai X, Walsh CA (2013) Somatic mutation, genomic variation, and neurological disease. Science 341:1237758. https://doi.org/10.1126/science.1237758

101. Poulin J-F, Tasic B, Hjerling-Leffler J, Trimarchi JM, Awatramani R (2016) Disentangling neural cell diversity using singlecell transcriptomics. Nat Neurosci 19:1131-1141. https://doi. org/10.1038/nn.4366

102. Proukakis C, Houlden H, Schapira AH (2013) Somatic alphasynuclein mutations in Parkinson's disease: hypothesis and preliminary data. Mov Disord 28:705-712. https://doi.org/10.1002/ mds. 25502

103. Proukakis C, Shoaee M, Morris J, Brier T, Kara E, Sheerin U-M et al (2014) Analysis of Parkinson's disease brain-derived DNA for alpha-synuclein coding somatic mutations. Mov Disord 29:1060-1064. https://doi.org/10.1002/mds.25883

104. Quadrato G, Brown J, Arlotta P (2016) The promises and challenges of human brain organoids as models of neuropsychiatric disease. Nat Med 22:1220-1228. https://doi.org/10.1038/ nm.4214

105. Rass U, Ahel I, West SC (2007) Defective DNA repair and neurodegenerative disease. Cell 130:991-1004. https://doi. org/10.1016/j.cell.2007.08.043
106. Regev A, Teichmann SA, Lander ES, Amit I, Benoist C, Birney E et al (2017) The human cell atlas. Elife 6:e27041. https://doi. org/10.7554/eLife.27041

107. Rehen SK, Yung YC, McCreight MP, Kaushal D, Yang AH, Almeida BSV et al (2005) Constitutional aneuploidy in the normal human brain. J Neurosci 25:2176-2180. https://doi. org/10.1523/JNEUROSCI.4560-04.2005

108. Richards SJ, Morris RJ, Raisman G (1985) Solitary magnocellular neurons in the homozygous Brattleboro rat have vasopressin and glycopeptide immunoreactivity. Neuroscience 16:617-623

109. Richardson DS, Lichtman JW (2015) Clarifying tissue clearing. Cell 162:246-257. https://doi.org/10.1016/j.cell.2015.06.067

110. Rovelet-Lecrux A, Hannequin D, Raux G, Le Meur N, Laquerrière A, Vital A et al (2006) APP locus duplication causes autosomal dominant early-onset Alzheimer disease with cerebral amyloid angiopathy. Nat Genet 38:24-26. https://doi. org/10.1038/ng1718

111. Sala Frigerio C, Lau P, Troakes C, Deramecourt V, Gele P, Van Loo $\mathrm{P}$ et al (2015) On the identification of low allele frequency mosaic mutations in the brains of Alzheimer's disease patients. Alzheimer's Dement 11:1265-1276. https://doi.org/10.1016/j. jalz.2015.02.007

112. Salk JJ, Schmitt MW, Loeb LA (2018) Enhancing the accuracy of next-generation sequencing for detecting rare and subclonal mutations. Nat Rev Genet 19:269-285. https://doi.org/10.1038/ nrg.2017.117

113. Sardo Lo V, Ferguson W, Erikson GA, Topol EJ, Baldwin KK, Torkamani A (2017) Influence of donor age on induced pluripotent stem cells. Nat Biotechnol 35:69-74. https://doi.org/10.1038/ nbt. 3749

114. Saxowsky TT, Doetsch PW (2006) RNA polymerase encounters with DNA damage: transcription-coupled repair or transcriptional mutagenesis? Chem Rev 106:474-488. https://doi. org/10.1021/cr040466q

115. Sedelnikova OA, Horikawa I, Zimonjic DB, Popescu NC, Bonner WM, Barrett JC (2004) Senescing human cells and ageing mice accumulate DNA lesions with unrepairable double-strand breaks. Nat Cell Biol 6:168-170. https://doi.org/10.1038/ncb1095

116. Shendure J, Akey JM (2015) The origins, determinants, and consequences of human mutations. Science 349:1478-1483. https:// doi.org/10.1126/science.aaa9119

117. Singer T, McConnell MJ, Marchetto MCN, Coufal NG, Gage FH (2010) LINE-1 retrotransposons: mediators of somatic variation in neuronal genomes? Trends Neurosci 33:345-354. https://doi. org/10.1016/j.tins.2010.04.001

118. Sjulson L, Cassataro D, DasGupta S, Miesenböck G (2016) Cellspecific targeting of genetically encoded tools for neuroscience. Annu Rev Genet 50:571-594. https://doi.org/10.1146/annurevgenet-120215-035011

119. Sleegers K, Brouwers N, Gijselinck I, Theuns J, Goossens D, Wauters J et al (2006) APP duplication is sufficient to cause early onset Alzheimer's dementia with cerebral amyloid angiopathy. Brain 129:2977-2983. https://doi.org/10.1093/brain/awl203

120. Song S, Gleeson JG (2018) Early life experience shapes neural genome. Science 359:1330-1331. https://doi.org/10.1126/scien ce.aat3977

121. Spira ME, Hai A (2013) Multi-electrode array technologies for neuroscience and cardiology. Nat Nanotechnol 8:83-94. https:// doi.org/10.1038/nnano.2012.265

122. Staahl BT, Benekareddy M, Coulon-Bainier C, Banfal AA, Floor SN, Sabo JK et al (2017) Efficient genome editing in the mouse brain by local delivery of engineered Cas9 ribonucleoprotein complexes. Nat Biotechnol 35:431-434. https://doi.org/10.1038/ nbt.3806

123. Sternberger LA, Harwell LW, Sternberger NH (1982) Neurotypy: regional individuality in rat brain detected by 
immunocytochemistry with monoclonal antibodies. Proc Natl Acad Sci USA 79:1326-1330

124. Suberbielle E, Sanchez PE, Kravitz AV, Wang X, Ho K, Eilertson K et al (2013) Physiologic brain activity causes DNA doublestrand breaks in neurons, with exacerbation by amyloid- $\beta$. Nat Neurosci 16:613-621. https://doi.org/10.1038/nn.3356

125. Swisa A, Kaestner KH, Dor Y (2017) Transcriptional noise and somatic mutations in the aging pancreas. Cell Metab 26:809811. https://doi.org/10.1016/j.cmet.2017.11.009

126. Szilard L (1959) On the nature of the aging process. Proc Natl Acad Sci USA 45:30-45

127. Telenti A, Perkins BA, Venter JC (2016) Dynamics of an aging genome. Cell Metab 23:949-950. https://doi.org/10.1016/j. cmet.2016.06.002

128. Uhler C, Shivashankar GV (2017) Regulation of genome organization and gene expression by nuclear mechanotransduction. Nat Rev Mol Cell Biol 18:717-727. https://doi.org/10.1038/ nrm.2017.101

129. Upton KR, Gerhardt DJ, Jesuadian JS, Richardson SR, SánchezLuque FJ, Bodea GO et al (2015) Ubiquitous L1 mosaicism in hippocampal neurons. Cell 161:228-239. https://doi. org/10.1016/j.cell.2015.03.026

130. van Den Hurk WH, Willems HJ, Bloemen M, Martens GJM (2001) Novel frameshift mutations near short simple repeats. J Biol Chem 276:11496-11498. https://doi.org/10.1074/jbc. M011040200

131. van Heesch S, Mokry M, Boskova V, Junker W, Mehon R, Toonen P et al (2013) Systematic biases in DNA copy number originate from isolation procedures. Genome Biol 14:R33. https ://doi.org/10.1186/gb-2013-14-4-r33

132. van Leeuwen F, van der Beek E, Seger M, Burbach $P$, Ivell $R$ (1989) Age-related development of a heterozygous phenotype in solitary neurons of the homozygous Brattleboro rat. Proc Natl Acad Sci USA 86:6417-6420

133. van Leeuwen FW, Burbach JP, Hol EM (1998) Mutations in RNA: a first example of molecular misreading in Alzheimer's disease. Trends Neurosci 21:331-335. https://doi.org/10.1016/ S0166-2236(98)01280-6

134. van Leeuwen FW, de Kleijn DPV, van den Hurk HH, Neubauer A, Sonnemans MAF, Sluijs JA et al (1998) Frameshift mutants of beta amyloid precursor protein and ubiquitin-B in Alzheimer's and Down patients. Science 279:242-247. https://doi. org/10.1126/science.279.5348.242

135. van Leeuwen FW, Evans DA, Meloen R, Sonnemans MAF (1994) Differential neurophysin immunoreactivities in solitary magnocellular neurons of the homozygous Brattleboro rat indicate an altered neurophysin moiety. Brain Res 635:328-330. https://doi.org/10.1016/0006-8993(94)91456-7

136. van Leeuwen FW, Fischer DF, Kamel D, Sluijs JA, Sonnemans MAF, Benne R et al (2000) Molecular misreading: a new type of transcript mutation expressed during aging. Neurobiol Aging 21:879-891. https://doi.org/10.1016/S0197-4580(00)00151-2

137. van Leeuwen FW, Hol EM, Hermanussen RW, Sonnemans MAF, Moraal E, Fischer DF et al (2000) Molecular misreading in nonneuronal cells. FASEB J 14:1595-1602

138. Verheijen BM, van Leeuwen FW (2017) Commentary: the landscape of transcription errors in eukaryotic cells. Front Genet 8:1760. https://doi.org/10.3389/fgene.2017.00219

139. Vermulst M, Bielas JH, Kujoth GC, Ladiges WC, Rabinovitch PS, Prolla TA et al (2007) Mitochondrial point mutations do not limit the natural lifespan of mice. Nat Genet 39:540-543. https ://doi.org/10.1038/ng1988

140. Vermulst M, Denney AS, Lang MJ, Hung C-W, Moore S, Moseley MA et al (2015) Transcription errors induce proteotoxic stress and shorten cellular lifespan. Nat Commun 6:8065. https://doi. org/10.1038/ncomms 9065

141. Vijg J, Suh Y (2013) Genome instability and aging. Annu Rev Physiol 75:645-668. https://doi.org/10.1146/annurev-physi ol-030212-183715

142. Walker C, Herranz-Martin S, Karyka E, Liao C, Lewis K, Elsayed W et al (2017) C9orf72 expansion disrupts ATM-mediated chromosomal break repair. Nat Neurosci 36(1221):e1. https ://doi.org/10.1038/nn.4604

143. Wei P-C, Chang AN, Kao J, Du Z, Meyers RM, Alt FW et al (2016) Long neural genes harbor recurrent DNA break clusters in neural stem/progenitor cells. Cell 164:644-655. https://doi. org/10.1016/j.cell.2015.12.039

144. Weissman IL, Gage FH (2016) A mechanism for somatic brain mosaicism. Cell 164:593-595. https://doi.org/10.1016/j. cell.2016.01.048

145. Woodworth MB, Girskis KM, Walsh CA (2017) Building a lineage from single cells: genetic techniques for cell lineage tracking. Nat Rev Genet 18:230-244. https://doi.org/10.1038/nrg.2016.159

146. Yang L, Chen L-L (2017) Enhancing the RNA engineering toolkit. Science 358:996-997. https://doi.org/10.1126/scien ce.aar2400

147. Yang W, Yuste R (2017) In vivo imaging of neural activity. Nat Methods 14:349-359. https://doi.org/10.1038/nmeth.4230

148. Yang Y, Herrup K (2007) Cell division in the CNS: protective response or lethal event in post-mitotic neurons? Biochim Biophys Acta 1772:457-466. https://doi.org/10.1016/j.bbadi s.2006.10.002

149. Yoon K-J, Ringeling FR, Vissers C, Jacob F, Pokrass M, JimenezCyrus D et al (2017) Temporal control of mammalian cortical neurogenesis by m6A methylation. Cell 171(877-889):e17. https ://doi.org/10.1016/j.cell.2017.09.003

150. Zeisel A, Muñoz-Manchado AB, Codeluppi S, Lönnerberg P, La Manno G, Juréus A et al (2015) Cell types in the mouse cortex and hippocampus revealed by single-cell RNA-seq. Science 347:1138-1142. https://doi.org/10.1126/science.aaa1934 